\title{
Fluvial sedimentation and its reservoir potential at foreland basin margins: A case study of the Puig-reig anticline (South-eastern Pyrenees)
}

\author{
Xiaolong Sun a,*, Juan Alcalde ${ }^{\mathrm{b}}$, Enrique Gomez-Rivas ${ }^{\mathrm{a}}$, Amanda Owen ${ }^{\mathrm{c}}$, Albert Griera ${ }^{\mathrm{d}}$, \\ Juan Diego Martín-Martín ${ }^{\mathrm{a}}$, David Cruset ${ }^{\mathrm{b}}$, Anna Travé ${ }^{\mathrm{a}}$ \\ a Departament de Mineralogia, Petrologia i Geologia Aplicada, Facultat de Ciències de la Terra, Universitat de Barcelona (UB), c/ Martí i Franquès s/n, 08028 Barcelona, Spain \\ b Geosciences Barcelona (GEO3BCN-CSIC), Lluís Solé i Sabarís s/n, 08028 Barcelona, Spain \\ c School of Geographical and Earth Sciences, University of Glasgow, University Avenue, G12 8QQ Glasgow, UK \\ d Departament de Geologia, Universitat Autònoma de Barcelona, 08193 Bellaterra, Cerdanyola del Vallès, Spain
}

\section{A R T I C L E I N F O}

\section{Article history:}

Received 9 May 2021

Received in revised form 31 August 2021

Accepted 2 September 2021

Available online 8 September 2021

Editor: Dr. Catherine Chagué

\section{Keywords:}

Fluvial fan

Reservoir potential

Fold

Ebro Foreland Basin

Pyrenees

\begin{abstract}
A B S T R A C T
Fluvial fans represent one of the dominant sedimentary systems at the active margins of non-marine foreland basins. The Puig-reig anticline at the north-eastern margin of the Ebro Foreland Basin (SE Pyrenees, Spain) exposes continuous outcrops of Late Eocene-Early Oligocene fluvial deposits, from proximal to medial fluvial fan environments. The proximal deposits are found in the north limb of the anticline, especially in the northwest zone. These deposits are characterised by conglomerates with minor interbedded sandstones, with thick and wide sheet-like geometries with unscoured or variably scoured basal surfaces. These are interpreted to be the deposits of unconfined flash floods and wide-shallow channel streams. The medial deposits, covering the rest of the anticline, consist of interbedded conglomerates, sandstones and claystones. These are interpreted to have been deposited from braided to meandering channel streams and overbank areas. Distal deposits are found towards the south, beyond the anticline, and are characterised by sandstone and clay deposits of terminal lobes and lacustrine deltas. This study assesses the impact of the primary depositional characteristics, diagenesis and deformation of the most heterolithic portion of the system, with implications for increasing our understanding of folded fluvial reservoirs. Diagenetic processes, mainly mechanical compaction and calcite cementation, resulted in overall low intergranular porosity, with limited relatively high porosity developed in sandstone lithofacies in the medial deposits. Deformation associated with thrusting and fold growth resulted in the formation of abundant fractures, with relatively high fracture intensities observed in sandstone lithofacies in the anticline crest. This study shows that post-depositional processes can both improve and diminish the reservoir potential of basin proximal fluvial deposits, through the development of fracture networks and by compaction-cementation. The comparison of the Puig-reig anticline with other similar settings worldwide indicates that foreland basin margin locations may be potential areas for effective reservoirs, even in the case of low intergranular porosity.
\end{abstract}

(c) 2021 The Author(s). Published by Elsevier B.V. This is an open access article under the CC BY license (http://creativecommons.org/licenses/by/4.0/).

\section{Introduction}

Reservoirs in foreland basins and adjacent fold-and-thrust belts host some of the most significant hydrocarbon resources in the world, e.g., the Zagros fold-and-thrust belt, the Persian Gulf, the Amu-Darya Basin, the Tarim Basin, and the Permian Basin (Mann et al., 2003; Wang et al., 2016). Hydrocarbon-bearing foreland basins are also one of the primary targets for low-carbon technologies such as carbon capture and storage (Sun et al., 2020). Alluvial and fluvial fans are the main deposits at active margins of non-marine foreland basins (DeCelles and Cavazza, 1999; Horton and Decelles, 2001; Ventra and Clarke, 2018). Alluvial fans are often dominated by conglomeratic facies, and can be

\footnotetext{
* Corresponding author.

E-mail address: xiaolong.sun@ub.edu (X. Sun).
}

concurrent with flow deposits of larger distributive fluvial systems, which transfer large volumes of coarse and fine sediments across basins (Williams et al., 1998; Weissmann et al., 2013, 2015). These coarse clastic belts are generally restricted in radial extent and are architecturally complex due to the lack of viable conceptual models. Thus, hydrocarbon exploration and development at continental basin margins are generally considered to be high risk with low return (Moscariello, 2018). However, alluvial fan and fluvial fan successions at basin margins may have good preservation potential if the subsidence rate is sufficient to generate accommodation for the resultant and significant sediment thickness (Moscariello, 2005). At basin margins, variable sedimentary characteristics from proximal to relatively distal environments, complex structural characteristics due to intensive deformation, and intensive diagenesis due to fluid flow of various local and external fluids can result in high levels of reservoir heterogeneity. Thus, reservoir 
quality in such settings is mainly controlled by their primary sedimentary characteristics, e.g., petrographic characteristics and stratigraphic sequence, as well as secondary diagenetic and fracturing processes that they experience (e.g., Morad et al., 2010; Taylor et al., 2010; Zhang et al., 2011; Watkins et al., 2018). Due to limited well data and seismic resolution of subsurface reservoirs, outcrop analogues play an important role in improving the accuracy of reservoir prediction in the subsurface (Howell et al., 2014), by providing reliable geological conceptual models and quantitative attribute information (Dichiarante et al., 2020). It is therefore essential to systematically study outcropping reservoir analogues to fully understand and predict the distribution and reservoir potential of alluvial-fluvial deposits in the subsurface.

The northern margin of the Ebro Foreland Basin and the adjacent South Pyrenean fold-and-thrust belt present multiple alluvial fans and distributive fluvial systems (Paleogene to Neogene). For example, the Huesca and Luna systems (Oligocene to Miocene) and a series of marginal alluvial fans in the northern margin of the central Ebro Basin have been well documented (Hirst and Nichols, 1986; Nichols and Hirst, 1998; Arenas et al., 2001; Yuste et al., 2004; Luzón, 2005; Nichols, 2005; Donselaar and Overeem, 2008; Martin et al., 2021). Similar Upper Eocene to Oligocene alluvial and fluvial systems developed in the north-eastern margin of the Ebro Basin. For example, the conglomerate-dominated Berga Group found near the frontal thrust sheets translated into fluvial deposits of the Solsona Formation towards the foreland basin (Sáez, 1987; Ford et al., 1997; Williams et al., 1998; Sáez et al., 2007; de Gibert and Sáez, 2009; Barrier et al., 2010). Based on outcrop investigations near the thrust sheets, Williams et al. (1998) interpreted the Berga Group as being the deposits from a type II alluvial fan as a consequence of repeated subaerial sheetflood and mass movement events (sensu Blair and McPherson (1994a, 1994b)). More recently, after examination of new outcrops across the Puig-reig anticline, Barrier et al. (2010) identified two distinct alluvial fans in the Berga Group. The first one is a large braided-stream-flow-dominated alluvial fan, which is related to the majority of the Berga Group deposits. The large alluvial fan was fed by a regional drainage basin including the south Pyrenean cover thrust sheets and the Pyrenean Axial Zone (Vergés, 2007). The second one is a small and local alluvial fan, which developed after the first large fan at the top of the Berga Group and is dominated by stream and gravity flows. This small alluvial fan was fed by a local drainage basin, extending only on the outermost cover thrust sheets.

Previous studies of the alluvial-fluvial deposits in the north-eastern Ebro Foreland Basin focused on the description and interpretation of the sedimentary environments and the interactions between sedimentation and tectonic activities (Williams et al., 1998; Sáez et al., 2007; Barrier et al., 2010; Carrigan et al., 2016). The Ebro Basin has been assessed as one of the priority regions for $\mathrm{CO}_{2}$ storage development in Spain (Sun et al., 2021a). The alluvial-fluvial strata show high potential to become effective reservoirs. For example, the Puig-reig anticline was assessed as a potential site for gas storage (Instituto Geológico y Minero de España, 1995). Besides, the well-exposed outcrops can provide excellent reservoir analogues to determine the reservoir potential of folded alluvial-fluvial successions at foreland basin margins. In this study, we focus on the Puig-reig anticline, which continuously exposes highquality outcrops that present variations of sedimentary facies across the structure. We quantitatively describe and interpret the lithofacies and sedimentary facies as well as their distribution over the Puig-reig anticline. In addition, based on a comprehensive analysis of lithofacies, cement, porosity, and fracture distribution, we determine the reservoir quality of different lithofacies considering their structural positions along the anticline. Based on the comparison between the Puig-reig anticline and other areas worldwide, we explore the reservoir potential of the studied anticline and other similar systems at foreland basin margins. This allows an assessment of how primary depositional characteristics as well as subsequent diagenetic and tectonic processes may influence the resource and storage potential of foreland basin proximal deposits.

\section{Geological setting}

The Pyrenees is a doubly verging orogenic belt that formed during the continental collision between the Iberian and European plates from Late Cretaceous to Miocene (Muñoz, 1992; Vergés et al., 2002). This orogenic belt is characterised by an antiformal stack of basementinvolved thrusts (the Axial Zone) surrounded by two fold-and-thrust belts that were transported to the north and south over the Aquitanian (France) and Ebro (Spain) foreland basins, respectively (Choukroune, 1989; Roure et al., 1989; Muñoz, 1992). The eastern part of the Ebro Basin displays an irregular shape bounded by the Pyrenees to the north and the Catalan Coastal Range to the southeast (Fig. 1A, B) (Vergés, 1993). The Vallfogona thrust represents the major frontal thrust between the SE Pyrenean thrust sheets and the Ebro Basin (Vergés et al., 1998). The Busa syncline and the Puig-reig anticline developed along the footwall of the Vallfogona thrust during Late Eocene and Oligocene (Fig. 1B, C) (Vergés, 1993). The Busa syncline developed over a blind thrust flat (Busa thrust) connected to the Vallfogona floor thrust. A geometric reconstruction allowed an interpretation of the Puig-reig anticline as the consequence of a duplex stack at depth (Vergés, 1993). The Puig-reig anticline is a km-scale south-verging gentle anticline with a flat hinge. The fold-trend is ESE/WNW, slightly oblique to the main Pyrenean structures (Vergés, 1993).

The Ebro Basin sediment fill includes synorogenic Paleocene to Miocene marine to non-marine deposits lying on top of the Paleozoic basement and Mesozoic sediments (Fig. 1C). The lower part of the Puig-reig anticline is mainly composed of deltaic sandstones and marine marls of the Banyoles and Igualada formations (Middle-to-Upper Eocene), which deposited between the Beuda and Cardona evaporitic formations (Vergés et al., 1992; Serra-Kiel et al., 2003a, 2003b). These deposits were followed by alluvial-fluvial sediments of the Berga Group and the Solsona Formation (Upper Eocene to Oligocene). These were deposited during the endorheic stage of the Ebro Basin (Puigdefàbregas et al., 1986, 1992) after a rapid transition from marine to continental depositional environments (Costa et al., 2010). To the north, at the footwall of the Vallfogona thrust, the Berga Group consists of $>2000$ m-thick alluvial and proximal fluvial conglomerates interbedded with minor sandstones and claystones, which displays growth strata (Ford et al., 1997; Suppe et al., 1997). To the south, the Berga deposits become progressively finer-grained and thinner-bedded fluvial conglomerates, sandstones and claystones of the Solsona Formation (Williams et al., 1998; Barrier et al., 2010). These fluvial deposits translated downstream to distal terminal deposits of the Súria Formation (Sáez et al., 2007). These terminal deposits graded into evaporites and calcareous lacustrine strata towards the centre of the Ebro Basin, e.g., the Barbastro, Castelltallat and Calaf formations (Sáez, 1987; Del Santo et al., 2000; Sáez et al., 2007). Collectively, these formations represent the basin proximal to basin centre facies within an internally drained continent basin. The subdivision of the Berga Group used in this study (Fig. 1D) follows the scheme of Williams et al. (1998). In the study area, we focus on the Camps de Vall-Llonga Formation, a sub-unit of the Middle Berga Group, that covers the northern zone of the Busa syncline and a large area of the Puig-reig anticline, and the Solsona Formation that is mainly observed in the south limb of the anticline (Fig. 1D, E).

\section{Outcrops and methods}

The Puig-reig anticline presents excellent outcrops along roads that cut through the structure in a roughly north-south direction, between the towns of Sant Llorenç de Morunys in the north and Solsona in the south (Fig. 1B, D). Eight high-resolution (decimetre-scale) stratigraphic logs with a total thickness exceeding $3000 \mathrm{~m}$ were created from eight cross-sections (Fig. 1D). Among these, logs A, B1, C, E and H represent 

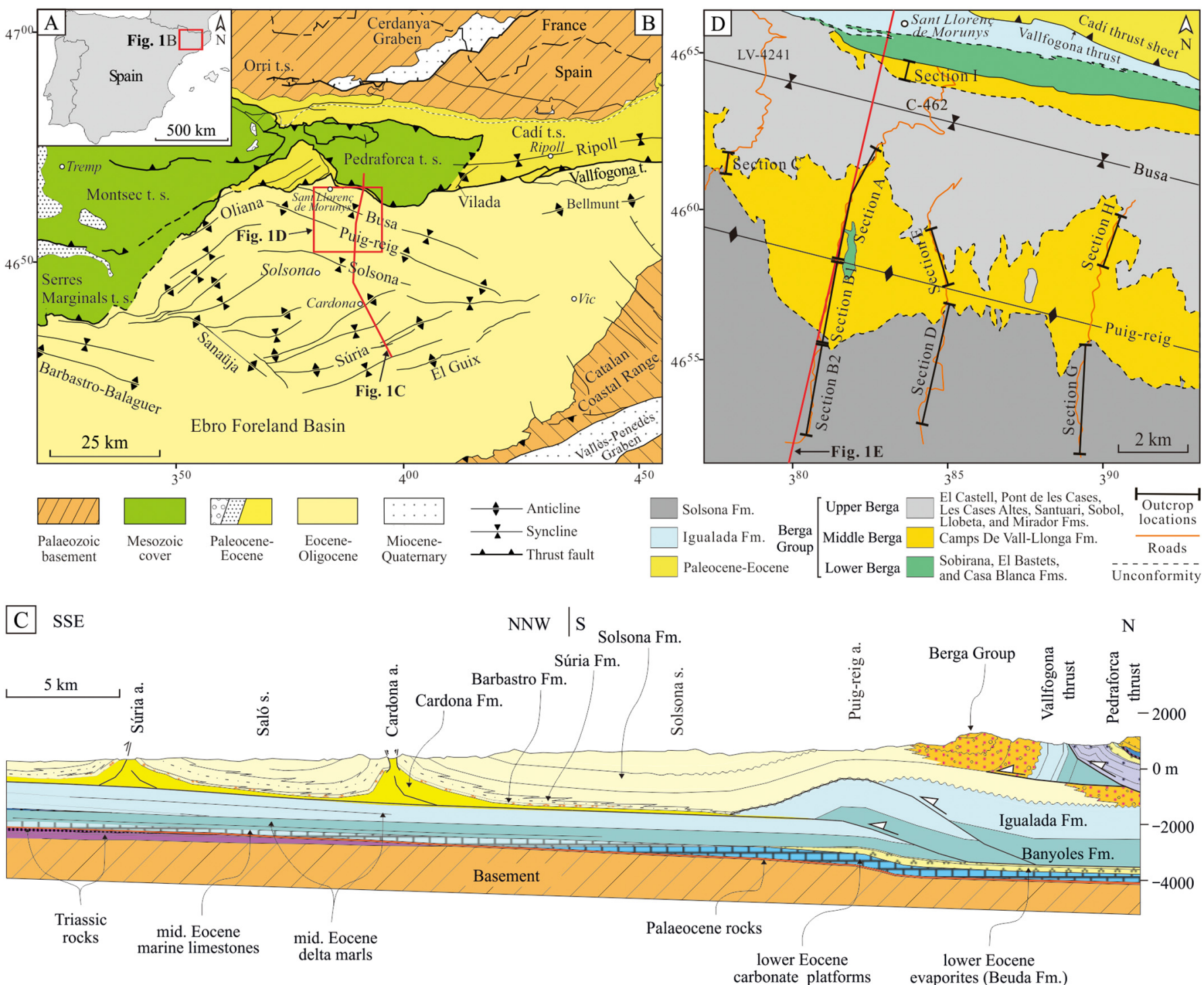

E SSW

carbonate platform

$\mathrm{NNE}-1500$

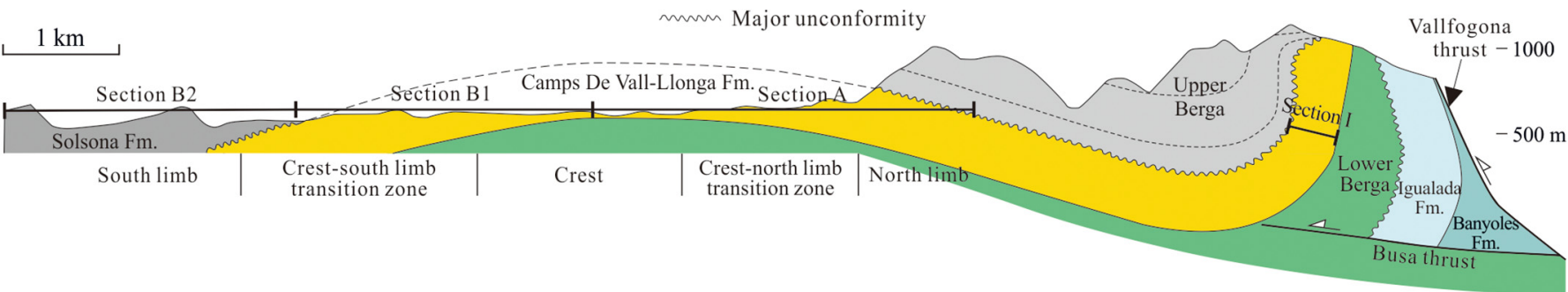

Fig. 1. (A-B) Geographical location and main structural units of the SE Pyrenean fold-and-thrust belt (Vergés, 1993) (t.s.: thrust sheet). (C) Geological cross section of the frontal part of the SE Pyrenean fold-and-thrust belt and the Ebro Foreland Basin (Vergés, 1993) (a.: anticline, s.: syncline). (D-E) Distribution of the Berga Group and the Solsona Formation and location of outcrops. The distribution of sedimentary units in panel D is based on the regional geological map of Catalonia (Institut Cartogràfic i Geològic de Catalunya, 2006). The formation subdivision of the Berga Group follows the scheme of Williams et al. (1998). Panel E is modified from Williams et al. (1998) and Barrier et al. (2010).

the strata of the Camps de Vall-Llonga Formation (Middle Berga Group), while $\operatorname{logs} \mathrm{B} 2$, D and G correspond to the Solsona Formation. The ca. 9 $\mathrm{km}$-long geological cross-section of the Puig-reig anticline (sections A, $\mathrm{B} 1$ and B2; Fig. 1E) is roughly parallel to the N-S shortening direction of the South-eastern Pyrenees and displays the continuous transition from proximal to relatively distal deposits. Moreover, log I of the Camps de Vall-Llonga Formation in the northern zone of the Busa syncline (Fig. 1D) from Barrier et al. (2010) was utilised in this study for comparison. The detailed sedimentary data acquired includes bed thickness and geometry, grain size and sedimentary structures, which collectively allow the identification of lithofacies and facies associations. The Puig-reig anticline was divided into five structural units from north to south (i.e., north limb, crest-north limb transition zone, crest, crestsouth limb transition zone and south limb; Fig. 1E). The terms 'proximal' and 'distal' were not used to name the structural units as in other studies (e.g., Ge et al., 1997; Martínez-Martínez et al., 2002) to avoid potential confusions with sedimentary system terms used to divide facies and depositional environments (i.e., proximal, medial and distal fan deposits). 
To determine rock composition, diagenetic alteration and intergranular porosity, 108 polished thin sections were made from collected samples. These samples are representative of the different lithofacies that can be defined in the area and different structural units of the anticline. Petrographic observations were made using a Zeiss Axiophot optical microscope and a Technosyn Cold Cathodoluminescence microscope, model $8200 \mathrm{Mk5}-1$ operating 16 to $17 \mathrm{kV}$ and 270 to $290 \mu \mathrm{A}$ gun current. Among these, 30 sandstone thin sections were selected for rock composition analysis using the point-counting method (300-400 points) to reveal potential compositional variations in different depositional environments. In total, 60 thin sections were analysed using NIS Elements and Image J software (Schneider et al., 2012) to quantitatively process microphotographs to determine cement content and intergranular porosity. Cement content equals the percentage content of calcite cement, which was determined using microphotographs in cathodoluminescence based on the colour differences between components (Fig. 2A). Intergranular porosity equals the percentage content of intergranular pores, which was determined using microphotographs in parallel Nicols (Fig. 2B). To quantitatively analyse the effect of diagenetic alteration on porosity loss, the original porosity $\left(P_{o}\right)$ of different lithologies was calculated based on Scherer's empirical formula (Scherer, 1987). The proportions of original porosity destroyed by cementation $\left(P L_{c e m}\right)$ and by compaction $\left(P L_{\text {com }}\right)$ of different lithologies were calculated based on Houseknecht's formulas (Houseknecht, 1987):

$P_{0}=20.91+22.9 / S_{0}$
$P L_{c e m}=\frac{P_{c e m}}{P_{o}} \times 100 \%$

$P L_{\text {com }}=\left(P_{o}-P_{\text {cem }}-P_{r}\right) / P_{o} \times 100 \%$

where $S_{o}$ is the Trask sorting coefficient of grain size, whose values of different lithologies were acquired from grain size analysis data from Sun (2018); $P_{\text {cem }}$ is the percentage content of cement; and $P_{r}$ is the percentage content of residual intergranular porosity.

Abundant fractures were observed in the folded sediments of the Puigreig anticline due to intensive tectonic deformation, which could have a significant effect on reservoir potential as important fluid migration pathways and storage space. Fracture attributes of the Puig-reig anticline were collected by Sun et al. (2021b) using the linear scanline method (Fig. 2C). Fracture intensity is the number of fractures per unit length of scanline and equals the reciprocal of fracture spacing. Fracture data of the Puig-reig anticline from Sun et al. (2021b) was incorporated into this study to comprehensively analyse the reservoir potential in the anticline.

\section{Results}

\subsection{Sedimentology}

Eight lithofacies were identified based on lithological characteristics and sedimentary structures, including three conglomerate facies, four sandstone facies, and one fine-grained (mud dominated) facies (Table 1). Five subsequent facies associations were then defined.
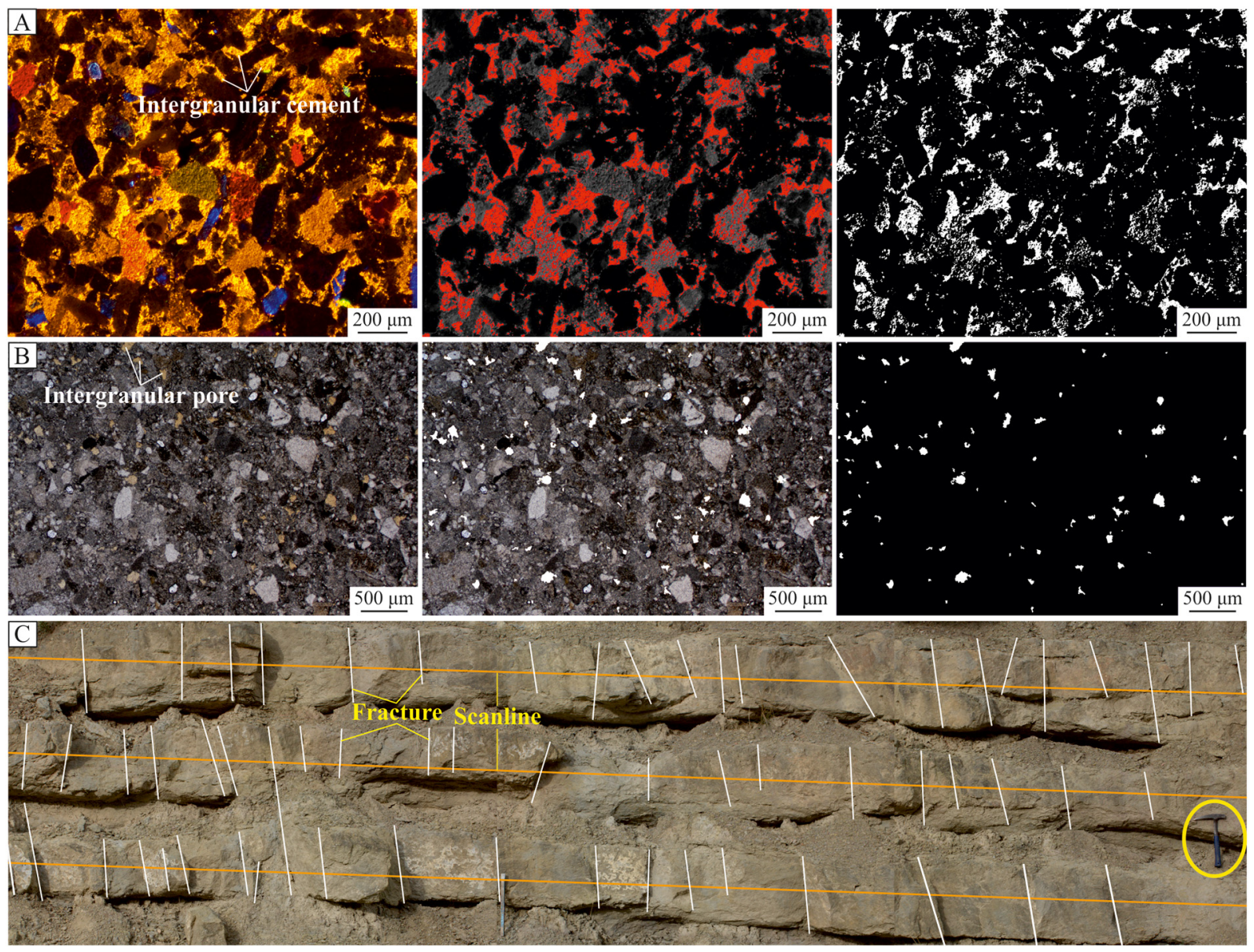

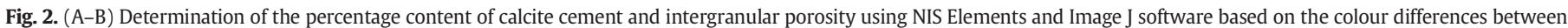
components. (C) Collection of fracture attributes using the linear scanline method (Sun et al., 2021b). 
Table 1

Subdivision and description of typical lithofacies.

\begin{tabular}{|c|c|}
\hline Lithofacies & Description \\
\hline Gsh1 & $\begin{array}{l}\text { Pebble to boulder, occasional outsize clasts, very poor sorting, clast- to reddish matrix-supported, mainly massive structure and minor rough-stratified structure, } \\
\text { unscoured or slightly scoured basal surface, sheet-like geometry. }\end{array}$ \\
\hline Gsh2 & Pebble to cobble, poor sorting, clast-supported, grey to reddish sand matrix, mainly massive structure, slightly or deep scoured basal surface, sheet-like geometry. \\
\hline Gch & Pebble to cobble, moderate to poor sorting, clast-supported, massive structure, scoured basal surface, channelised geometry. \\
\hline Smi & Reddish to grey fine to coarse sandstone, mainly massive structure, tabular geometry or sandstone lens, limited burrows. \\
\hline Sm & Mainly grey medium and coarse sandstone, massive structure, tabular geometry, limited burrows. \\
\hline Sl & Mainly fine to very fine sandstone, parallel bedding structure and minor cross bedding structure, tabular geometry, common burrows. \\
\hline Sch & Medium to coarse sandstone, scattered gravelly clasts or muddy rip-up clasts, massive structure, channelised geometry. \\
\hline $\mathrm{F}$ & Claystone to siltstone, tabular geometry, intensive weathering, erosion and pedogenesis, very common trace fossils. \\
\hline
\end{tabular}

\subsubsection{Lithofacies}

4.1.1.1. Conglomerate lithofacies (Gsh1, Gsh2 and Gch). Based on bed geometry (sheet-like and channelised geometries) and subtle internal lithological differences, the conglomerate lithofacies is subdivided into three subfacies (Gsh1, Gsh2 and Gch). All subfacies have polygenic clasts composed of carbonate, siliciclastic, igneous and metamorphic lithologies. In subfacies Gsh1, the clasts consist of very poorly sorted and subrounded to subangular pebbles to small boulders, with occasional outsize carbonate clasts. This lithofacies is clast- to matrix-supported. The matrix consists of reddish sands to small pebbles and lacks clays (Fig. 3A). Gsh1 conglomerate bodies tend to present a massive structure and minor rough-stratified layers, unscoured or slightly scoured basal surfaces (Fig. 3B), and a sheet-like geometry. The thickness of a single bed can range from 1 to $6 \mathrm{~m}$ (Fig. 4A), while bed associations can be up to around $50 \mathrm{~m}$. Horizons can be traced over several kilometres using satellite imagery. Gsh1 is only found in the upper part of $\log C$, in the northwest zone of the Puig-reig anticline.

Subfacies Gsh2 has relatively smaller grain size and lower matrix content compared to subfacies Gsh1, and stratified structure and unscoured basal surfaces are rarely observed. This lithofacies is composed of poorly sorted and subrounded pebbles to cobbles. It is mainly clast-supported and contains grey to reddish matrix of fine to coarse sands (Fig. 3C). Gsh2 conglomerate bodies are massive, and have scoured basal surfaces with different scour intensities (Fig. 3D), and a sheet-like geometry. The thickness of a single bed generally ranges between 1 and $5 \mathrm{~m}$, while bed associations can be up to around $50 \mathrm{~m}$ (Fig. 4B). Gsh2 develops in the north limb, mainly in $\log C$ and the upper part of logs $\mathrm{A}$ and $\mathrm{E}$.

Subfacies Gch consists of moderately to poorly sorted and subrounded pebble to small cobble size clasts, which tend to be clastsupported with grey, fine to coarse sand matrix (Fig. 3E). Gch conglomerate bodies generally present channelised geometries and deep scoured basal surfaces (Fig. 3F), which differ from Gsh1 and Gsh2 conglomerate bodies. Gch presents lateral wedge-out and changes laterally and vertically to sandstones and claystones (Sm, Sl and F) (Fig. 4C, D). The thickness of a single bed generally ranges from 0.5 to $4 \mathrm{~m}$. Gch is the most widespread conglomerate lithofacies, which develops in most areas of the anticline except for the south limb.

4.1.1.2. Sandstone lithofacies (Smi, Sm, Sl and Sch). Subfacies Smi includes reddish to grey, medium and coarse sandstones and minor fine sandstones. These sandstone layers tend to present a massive structure with locally scattered gravel clasts of a few millimetres in size, and in some minor cases parallel bedding can be observed. Beds range in thickness from 0.2 to $2 \mathrm{~m}$. They can have a tabular geometry and be interbedded with Gsh2 (Fig. 3G) or occur as sandstone lenses within Gsh1 and Gsh2 conglomerate bodies that rapidly pinch out laterally (Fig. 3H). Very limited large (with diameter up to $1.5 \mathrm{~cm}$ ) vertical or oblique burrows are observed in these coarse sand deposits. Smi mainly develops in the north limb of the anticline.
Subfacies Sm is mainly composed of grey medium to coarse sandstones. Sm has relatively lower matrix contents and better grain sorting than Smi. Sm sandstone layers tend to present a massive structure with bed thickness ranging from 0.5 to $1.5 \mathrm{~m}$ (Fig. 3I). They show a tabular geometry with sharp and unscoured basal surfaces. They are commonly found above Gch layers or interbedded with laminated fine sandstones (Sl) and claystones (F). Limited burrows are observed in these coarse sandstone layers. Sm is one of the dominant lithofacies and is widely observed across the anticline.

Subfacies $\mathrm{Sl}$ is composed of grey, fine to very fine sandstones and minor medium sandstones. Parallel bedding is the most common structure (Fig. 3I), while cross bedding is occasionally observed (Fig. 3J). Sl tends to be interbedded with Sm and fine deposits (F). Vertical, oblique or horizontal burrows are more commonly present in these fine sandstones (Fig. 3K). Sl is another dominant lithofacies and widely developed across the anticline.

Subfacies Sch is composed of grey, medium to coarse sandstones, with scattered gravelly clasts (Fig. 3L, M). It has a similar massive structure as Sm layers, but has a channelised geometry with scoured surfaces and generally develops at the bottom of lithofacies association (Fig. 4E, F). Muddy rip-up clasts are sometimes present at the bottom of Sch due to the scour and re-deposition of fine deposits (Fig. 3M). Sch mainly develops in the south limb of the anticline.

4.1.1.3. Fine-grained lithofacies $(F)$. Lithofacies $F$ includes reddish to grey siltstones and claystones. They occur as tabular bodies and are commonly interbedded with Sm and Sl (Fig. 3N). Small burrows and other trace fossils, e.g., Taenidium barretti and Helminthoidichnites (de Gibert and Sáez, 2009) are very common in these fine deposits (Fig. 30). These deposits tend to be affected by intensive weathering, erosion and pedogenesis. Lithofacies $\mathrm{F}$ is widely developed across the anticline. Bed thickness varies significantly from around $10 \mathrm{~cm}$ to up to around 4.5 $\mathrm{m}$, and increasing in presence from the north to the south limb of the anticline.

\subsubsection{Lithofacies associations and sedimentary environments}

4.1.2.1. Proximal fluvial fan: unconfined flash flood deposits with no overbank deposits (LAp1). LAp1 association is dominated by lithofacies Gsh1 with limited Smi interlayers that generally pinch out laterally as sandstone lenses (Figs. 4A, 5A). These lihtofacies combine into large and structureless sheet-like bodies of coarse deposits with unscoured or slightly scoured basal surfaces (Fig. 3B). These characteristics collectively represent unconfined flow of a flashy nature (Blair and McPherson, 1994a; Nichols and Hirst, 1998; Williams et al., 1998). This association is dominantly found in the northwest portion of the Puig-reig anticline, i.e., the upper part of $\log \mathrm{C}$.

4.1.2.2. Proximal fluvial fan: unconfined flash flood and wide-shallow channel deposits with limited overbank deposits (LAp2). LAp2 association is dominated by lithofacies Gsh2 and Smi with limited Sm, Sl and F (Figs. 4B, 5B). Lithofacies Smi can occur as stable tabular layers or 



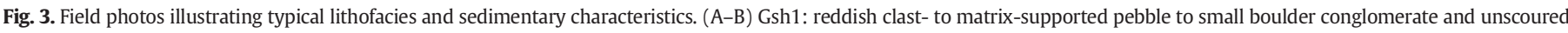

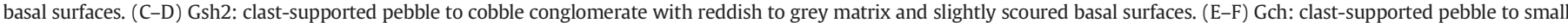

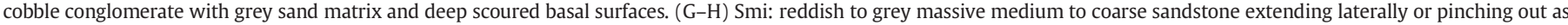



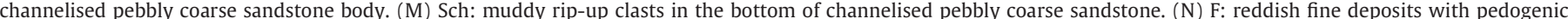
characteristics. (O) Abundant trace fossils in fine-grained deposits.

pinch-out lenses in Gsh2. This association presents large and structureless sheet-like geometries, with scoured surfaces of varying intensities (Figs. 3D, 4B). These features can collectively represent unconfined flow of a flashy nature or wide-shallow channel flow (Arenas et al., 2001; Yuste et al., 2004; Luzón, 2005). This association is dominantly found in the north limb of the anticline, mainly in $\log C$ and the upper part of logs $\mathrm{A}$ and $\mathrm{E}$.

4.1.2.3. Medium fluvial fan: channel fill deposits with overbank deposits (LAm1 and LAm2). LAm1 association is composed of lithofacies Gch,
Sm, Sl, and F. An overall fining-upward trend is observed in this lithofacies association, from channelised $\mathrm{Gch}$ to tabular and interbedded Sm, Sl and F lithofacies (Figs. 4C, 5C). Sometimes, vertical accretion of channels can be observed (Fig. 4D). These features can collectively represent the deposits of braided channel streams and overbank areas (Nichols and Hirst, 1998; Arenas et al., 2001). This lithofacies association is distributed across the anticline except for the south limb of the anticline. LAm2 association is composed of lithofacies Sch, Sm, Sl and F and presents an overall fining-upward trend from channel fill sandy deposits to overbank fine deposits (Figs. 4E, 5D). Compared to LAm1 





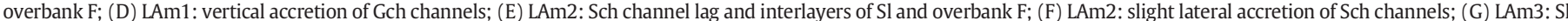
and stable overbank F incised by Sch channel.

association, lithofacies Sch replaces Gch conglomerate bodies as channel lag deposits in LAm2 association. In addition, this association has more overbank fine deposits and occasional lateral accretion of channels (Fig. 4F). This association is dominantly found in the south limb and slightly developed in the crest and crest-south limb transition zone of the anticline. Thus, LAm2 association is deposits found further downstream but still in a medial setting, in comparison to LAm1. These features can collectively represent the sedimentary environment of braided to meandering channel streams and overbank areas. Such sandy meandering channels in medial fluvial system have also been 


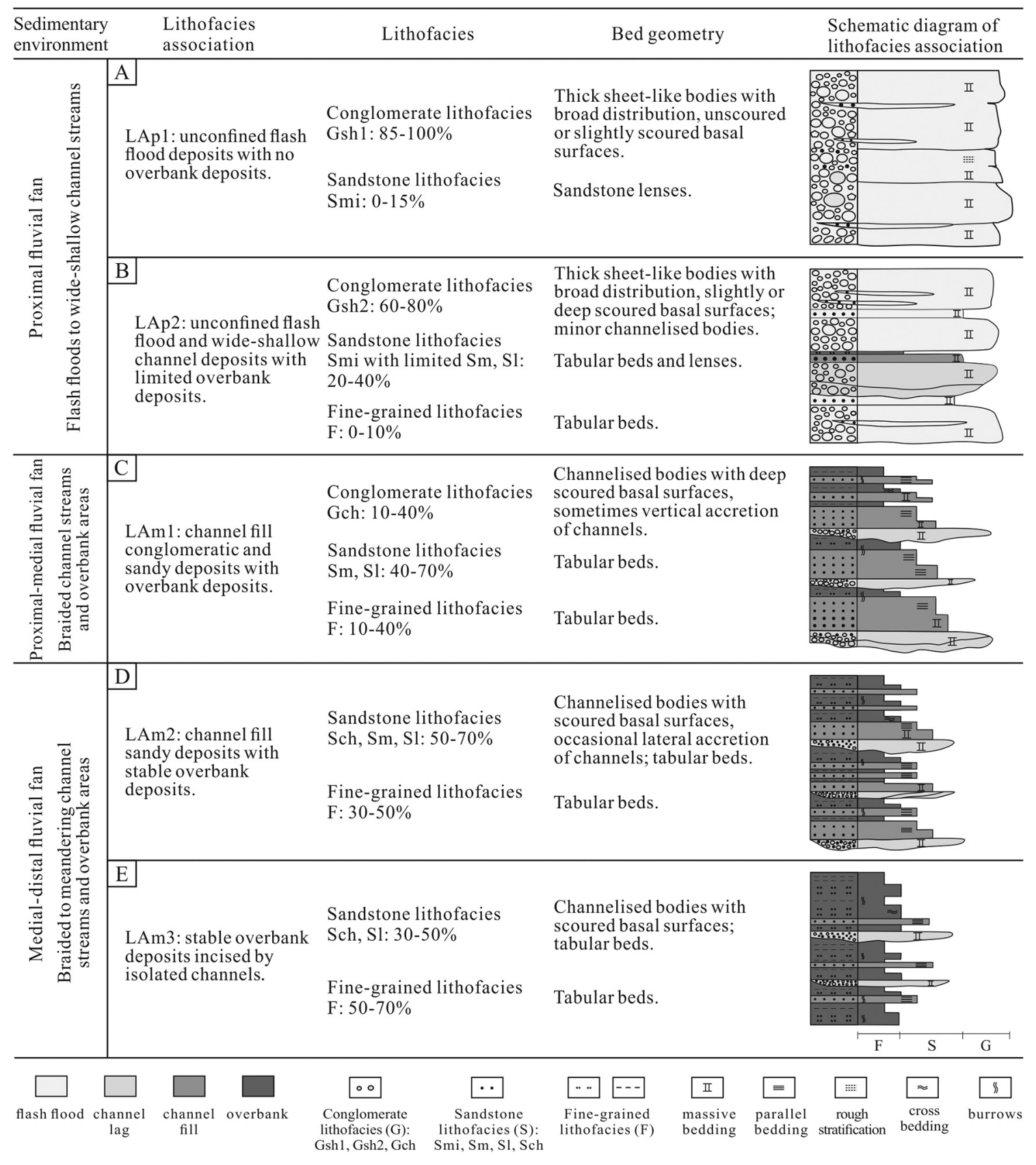

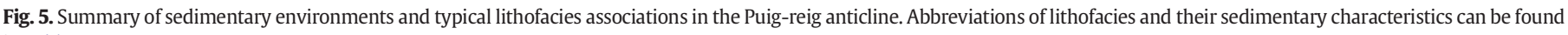
in Table 1.

documented at the north margin of the Ebro Basin (e.g., Arenas et al., 2001; Luzón, 2005).

4.1.2.4. Medium fluvial fan: stable overbank deposits incised by isolated channels (LAm3). LAm3 association is composed of lithofacies Sch, Sl and $\mathrm{F}$, which is characterised by channelised Sch bodies incising stable tabular F and Sl deposits (Figs. 4G, 5E). Compared to LAm2 association, LAm3 contains more overbank fine deposits and isolated channels. This association could have been deposited from isolated meandering channels or the wings of channels. This association is occasionally found in the south limb of the anticline.

4.1.2.5. Distribution of lithofacies associations and sedimentary environments. The characteristics of the described lithofacies associations (Fig. 5) can collectively represent deposits from a proximal to medial fluvial fan system in the Puig-reig anticline. The proximal deposits are mainly composed of LAp1 and LAp2 lithofacies associations deposited from unconfined flash floods and wide-shallow channels, with minor LAm1 lithofacies association. The medial deposits are composed of LAm1 to LAm3 lithofacies associations deposited from braided to meandering channel streams and overbank areas. The relatively proximal part of the medial fluvial fan (proximal-medial fan) is mainly composed of LAm1 and limited LAm2 associations, while the relatively distal part of the medial fluvial fan (medial-distal fan) is mainly composed of LAm2 and limited LAm 1 and LAm3 associations. Similar facies associations and sedimentary models have been described in the north margin of the central Ebro Basin (e.g., Hirst and Nichols, 1986; Nichols and Hirst, 1998; Arenas et al., 2001; Yuste et al., 2004; Luzón, 2005). In this study, three well sections have been built for the upper Camps de Vall-Llonga Formation (Section 1 and Section 2) and the lower Solsona Formation 

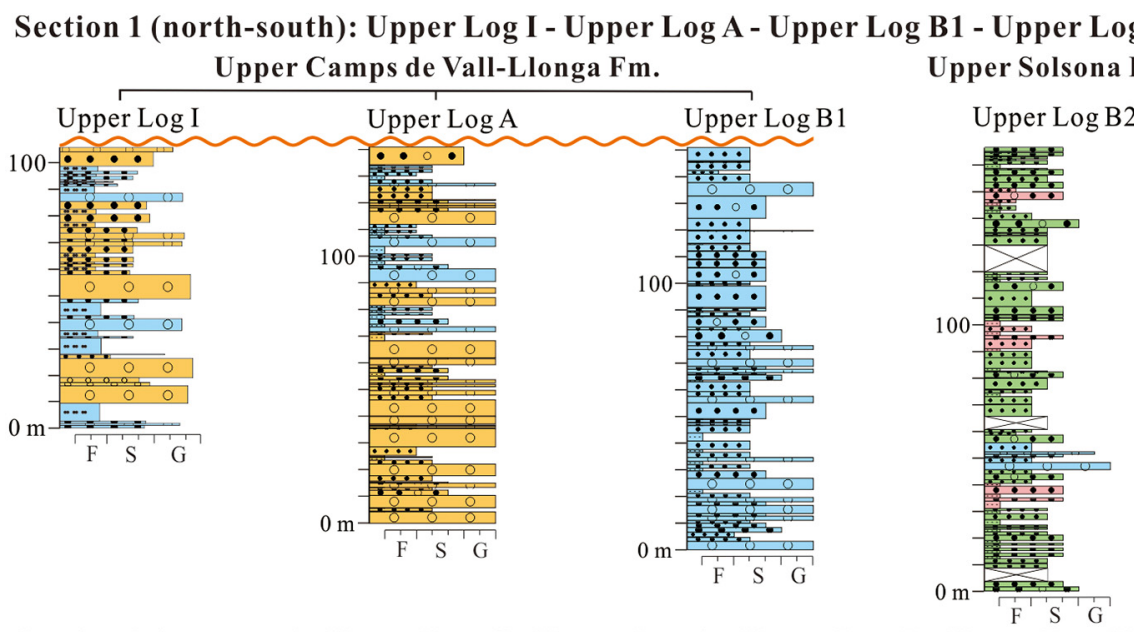

Section 2 (west-east): Upper Log C - Upper Log A - Upper Log E - Upper Log H Upper Camps de Vall-Llonga Fm.

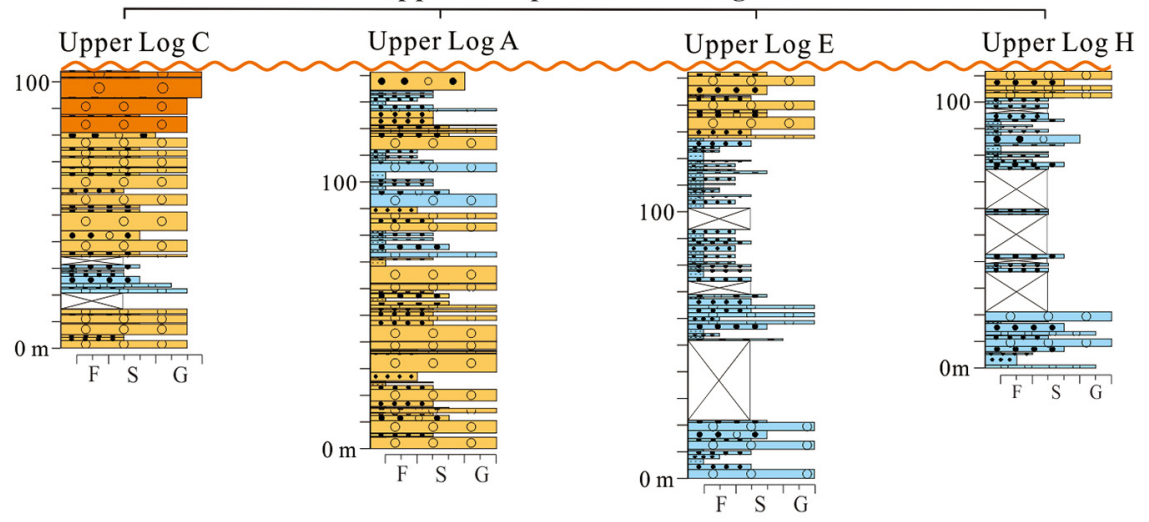

Section 3 (west-east): Lower Log B2 - Middle Log D - Middle Log G Lower Solsona Fm.



Fig. 6. Correlation of stratigraphic logs for the upper Camps de Vall-Llonga Formation (Section 1 and Section 2) and the Solsona Formation (Section 3). The locations of the stratigraphic logs can be found in Fig. 7A. Log I is modified from Barrier et al. (2010). 


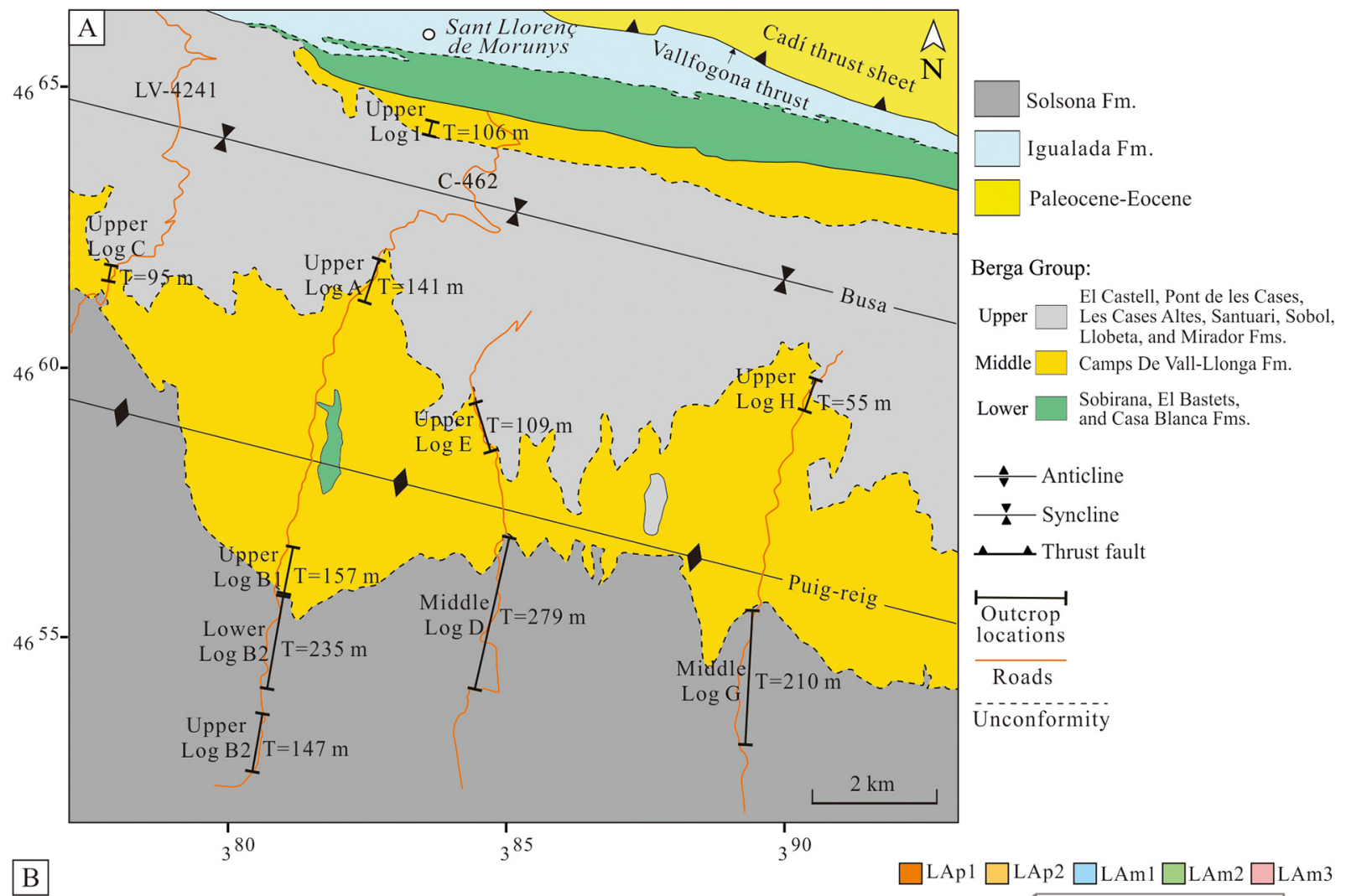

Section 1 (north-south): Upper Log I - Upper Log A - Upper Log B1 - Upper Log B2
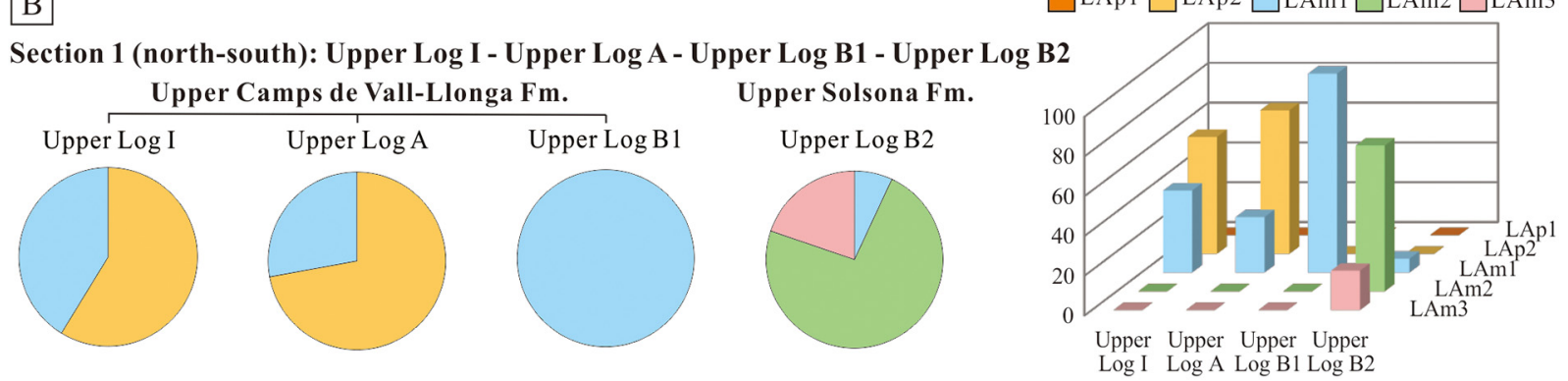

Section 2 (west-east): Upper Log C - Upper Log A - Upper Log E - Upper Log H Upper Camps de Vall-Llonga Fm.
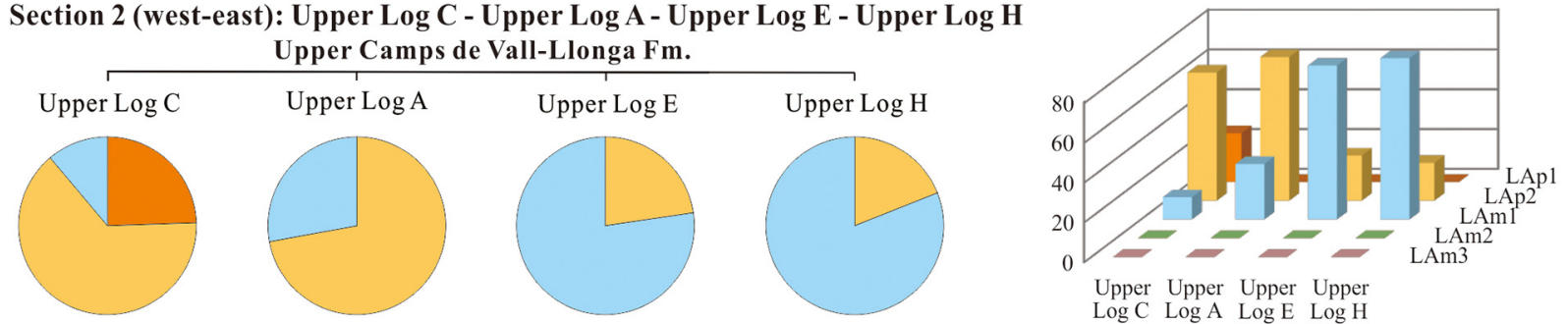

Section 3 (west-east): Lower Log B2 - Middle Log D - Middle Log G
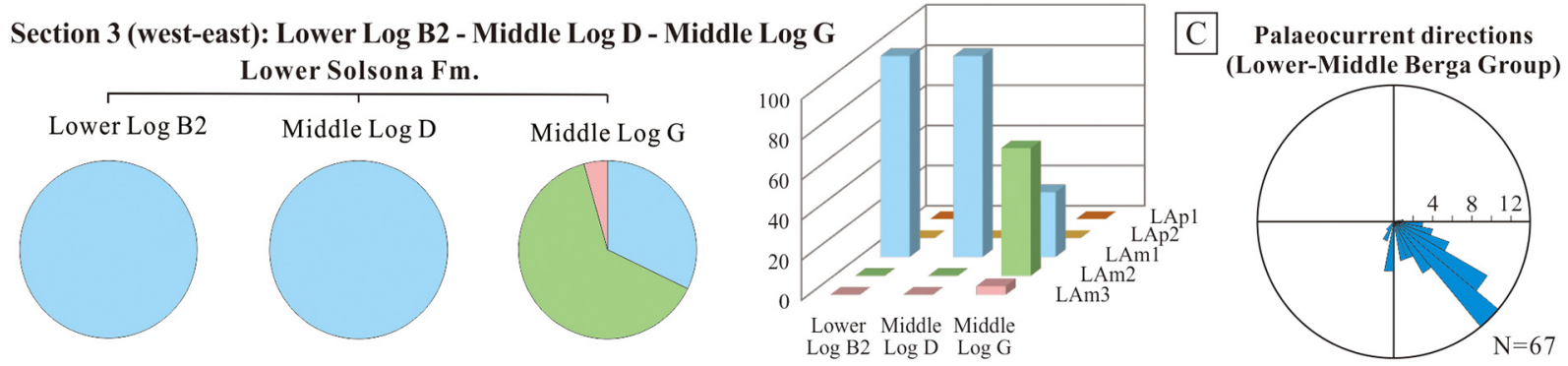



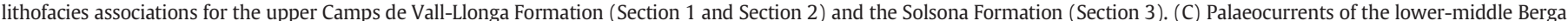
Group from Barrier et al. (2010) and Williams et al. (1998) indicate an overall south-east direction. $N$ is the number of palaeocurrents. 
(Section 3) to analyse the distribution of the identified lithofacies associations (Fig. 6). The locations of the stratigraphic logs used for correlations are displayed in Fig. 7A. The upper Camps de Vall-Llonga Formation mainly consists of LAp1, LAp2 and LAm1 lithofacies associations. LAp1 and LAp2 associations decrease significantly from upper $\log C$ to upper $\log \mathrm{H}$ (west to east) and from upper $\log \mathrm{I}$ to upper $\log$ B1 (north to south), which were replaced by LAm1 (Fig. 7B). The Solsona Formation mainly consists of LAm1, LAm2 and LAm3 lithofacies associations. LAm1 association decreases from lower log B2 to middle $\log \mathrm{G}$ (west to east) and is gradually replaced by LAm2 and LAm3 associations (Fig. 7B). The distribution of lithofacies associations in the Puig reig anticline (Figs. 6, 7) indicates a proximal to medial fluvial system with an overall south-east downstream trend. The palaeocurrents of the lower-middle Berga Group from Barrier et al. (2010) also indicate a south-east downstream direction (Fig. 7C).

\subsection{Reservoir characteristics}

Based on Folk's (1980) sandstone classification scheme, all sandstone samples of the studied area plot within the litharenite field, with lithic content ranging from $60 \%$ to $90 \%$, quartz content ranging from $5 \%$ to $30 \%$, and very limited feldspar content (Fig. 8A). Based on Zuffa's (1980) classification scheme of hybrid arenites, these samples mainly plot in the carbonate extrarenite field with a minority that plot in the non-carbonate extrarenite field (Fig. 8B). The content of carbonate extrabasinal grains mainly ranges from $40 \%$ to $70 \%$, while the content of non-carbonate extrabasinal grains, including non-carbonate lithic, quartz, feldspar, mainly ranges from $30 \%$ to $60 \%$. The proximal fluvial fan has a slightly higher content of carbonate extrabasinal grains, compared to the medial fluvial fan. However, as can be seen in Fig. 8, no portion of the fan has a distinctive compositional signature with overlap between the different samples.

Calcite is the dominant cement in the intergranular porosity of the fluvial deposits. Two generations of calcite cements have been identified based on petrographic observations. The first generation only filled a very limited fraction of intergranular porosity. This cement generally precipitated along clast edges and presents non-luminescent to bright luminescent zonation under cathodoluminescence (Fig. 9A, B). The second generation occluded most intergranular pores of all lithofacies across different structural units of the anticline, and present homogeneously bright orange luminescence (Fig. 9C, D). This cement filled the residual intergranular pores where $\mathrm{Cc} 0$ precipitated along clast edges (Fig. 9A, B), indicating that it developed after the first generation. The percentage content of calcite cement mainly ranges from $5 \%$ to $16 \%$ (Fig. 10), with around 95\% of the measured samples located in this range and an average value of $11.6 \%$. Cement content shows a variation across the different lithofacies, where sandstone lithofacies show slightly higher cement content compared to conglomerate and finegrained lithofacies. Due to intensive calcite cementation, only limited intergranular pores remained open, resulting in an overall low porosity of the fluvial deposits. Intergranular porosity mainly ranges from $0 \%$ to $2 \%$ (Fig. 10), with around $85 \%$ of the measured samples located in this range and an average value of $1.1 \%$. Limited samples present relatively high porosity concentrated in lithofacies Sch and Sm in the crest, crest-limb transition zones and south limb of the anticline, mainly ranging from $2 \%$ to $8 \%$ (Fig. 10). There is no clear correlation between cement content and porosity (Fig. 11A).

Original porosity of different lithologies was calculated based on the Trask sorting coefficient data of fluvial to deltaic sediments of the Huagang Formation in the Xihu Depression (Table 2; Sun, 2018). The sorting coefficient of siltstone and sandstone mainly ranges from 1.3 to 2.3 , resulting in original porosity between $31 \%$ and $39 \%$ with an average of around $35 \%$. The sorting coefficient of conglomerate mainly ranges from 1.6 to 2.6 , resulting in original porosity between $30 \%$ and $35 \%$ with an average of around $32 \%$. Calcite cementation and compaction are the most significant diagenetic processes affecting porosity evolution of the fluvial deposits in the Puig-reig anticline. Original porosity destroyed by cementation mainly ranges from $20 \%$ to $50 \%$, whereas that destroyed by compaction mainly ranges from $40 \%$ to $80 \%$ (Fig. 12A, B). Limited samples with relatively high porosity concentrate in Sch and Sm lithofacies and have porosity destroyed by cementation and compaction mainly ranging from $30 \%$ to $50 \%$ and from $40 \%$ to $60 \%$, respectively (Fig. 12A).

Fracture intensity data was obtained from previous research in the Puig-reig anticline (Sun et al., 2021b). Fine-grained lithofacies tend to experience intensive weathering, erosion and pedogenesis and thus impede the identification of fracture attributes in these layers. Thus, fracture attributes were only measured in conglomerate and sandstone lithofacies using the linear scanline method (Fig. 2C). Fracture intensity mainly ranges from $0.5 \mathrm{~m}^{-1}$ to $2.5 \mathrm{~m}^{-1}$ and varies significantly across different structural units of the anticline (Fig. 10). The anticline crest and crest-limb transition zones have higher values than the south and north limbs. Fig. 11B shows a clear negative correlation between fracture intensity and distance to the anticline hinge. In the same structural unit, fracture intensity also varies significantly in different lithofacies. Sandstone lithofacies present higher values than conglomerate lithofacies in the anticline crest, crest-limb transition zones and north limb (Fig. 10). In the south limb, Sl has higher fracture intensity than Sch and Sm lithofacies. In addition, Fig. 11C shows a clear negative correlation between fracture intensity and bed thickness.

\section{Discussion}

\subsection{Fluvial fan sedimentary environments}

Previous studies interpreted the whole Berga Group as alluvial fan deposits that wedge out into fluvial fan deposits of the Solsona Formation (Williams et al., 1998; Barrier et al., 2010). However, here we

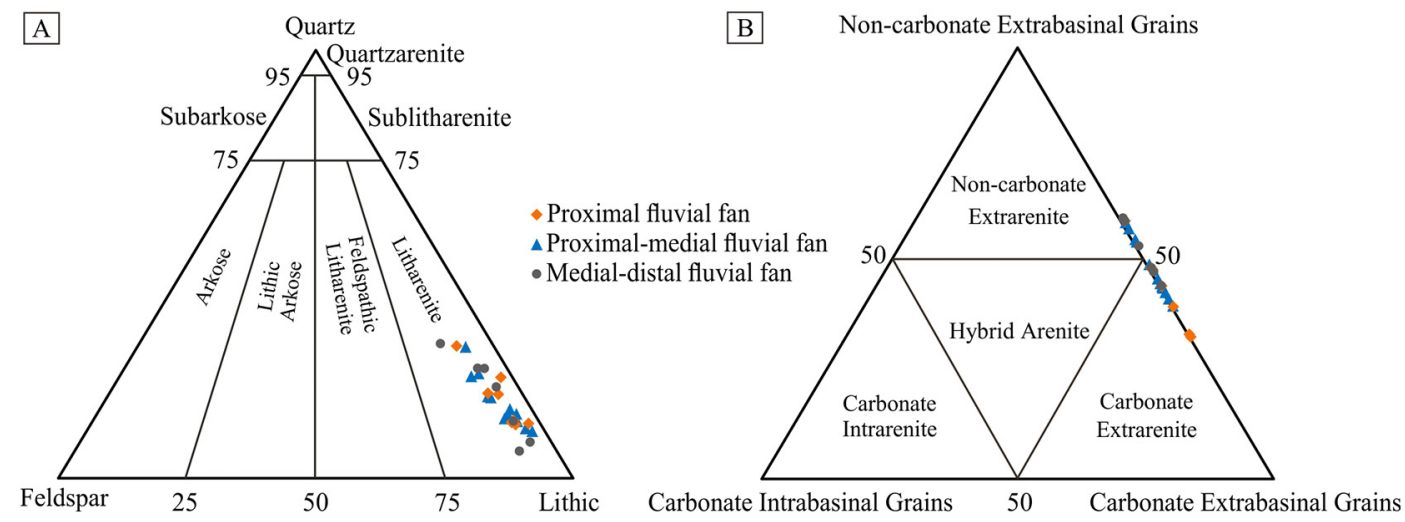

Fig. 8. Classification of sandstones based on framework grain composition after (A) Folk's (1980) and (B) Zuffa's (1980) classification schemes. 

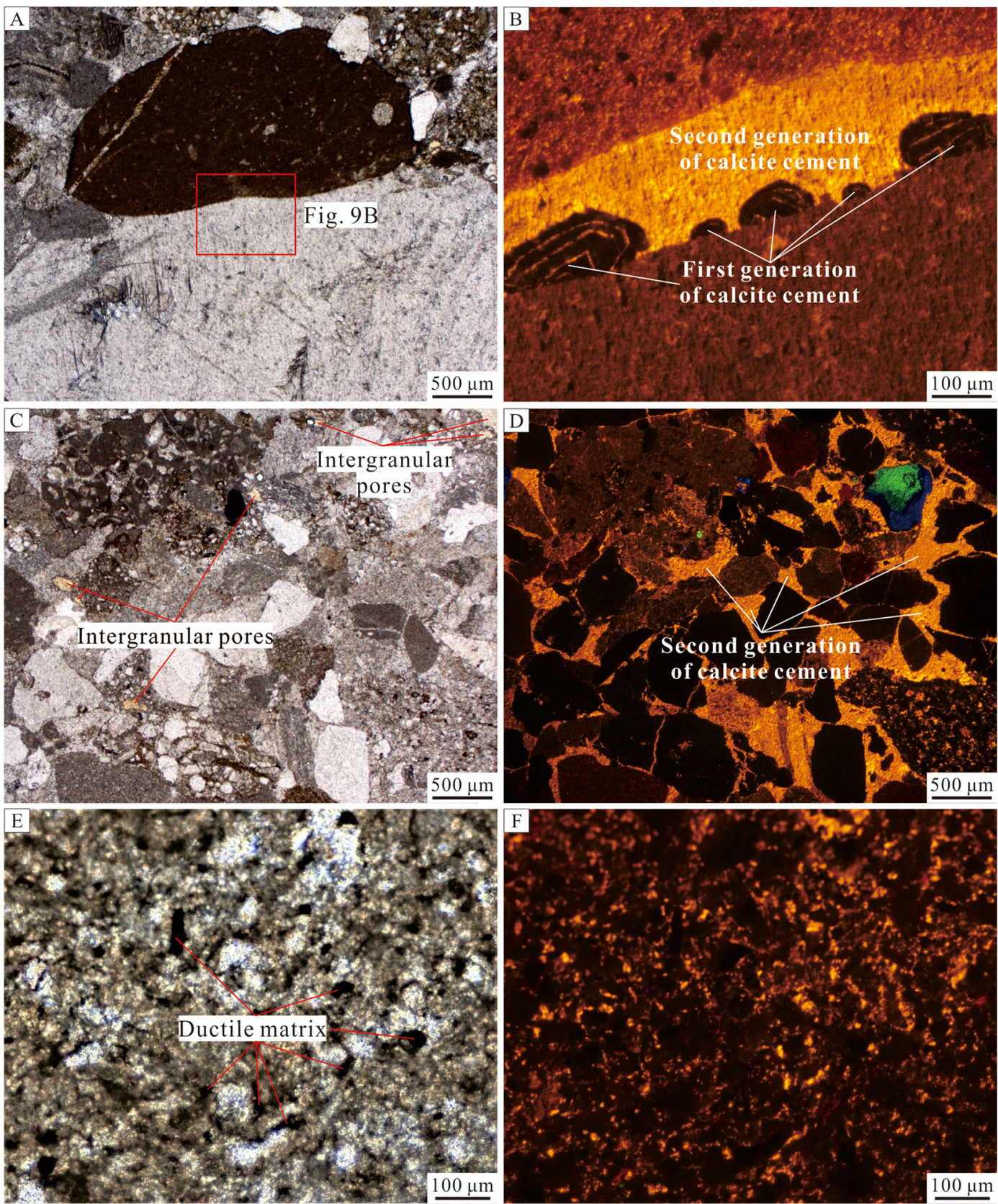

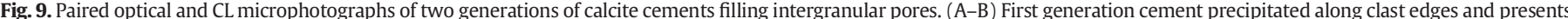


Very fine sandstone to siltstone presents high content of ductile matrix and low content of calcite cement.

focus on the analysis of the Camps de Vall-Llonga Formation of the Berga Group and the Solsona Formation in the Puig-reig anticline. They are interpreted as deposited from a proximal-medial fluvial system, based on the comprehensive analyses of the drainage basin, fan size and sedimentary characteristics and the comparison to other similar sedimentary systems in the central Ebro Basin (Hirst and Nichols, 1986; Arenas, 1993; Nichols and Hirst, 1998; Arenas et al., 2001; Luzón, 2005).

Alluvial fan deposits are sourced by areal-limited drainage basins and are dominated by sheetflood and debris flow processes, whereas fluvial fan deposits tend to have larger drainage basins with long-term expansion and integration of catchments and channelised streams developing on the system (Moscariello, 2018; Ventra and Clarke, 2018). The Camps de Vall-Llonga and Solsona deposits are composed of polygenic clasts, including both carbonate and non-carbonate clasts
(Fig. 8B). As noted by Riba (1976), the non-carbonate clasts of acidintermediate plutonic rocks, Permo-Triassic red beds, Carboniferous micro-conglomerates, rare metasedimentary rocks and basic igneous rocks, all come from the basement of the Pyrenean Axial Zone. The varied carbonate clasts reflect source areas in the Mesozoic-Cenozoic series of the south Pyrenean thrust sheets and the Pyrenean Axial zone (Devonian carbonates). The polygenic compositions reveal the drainage basin of the Camps de Vall-Llonga and Solsona deposits extending from the south Pyrenean thrust sheets to the Pyrenean Axial Zone, which is consistent with the large and regional-scale drainage basin of fluvial deposits.

Alluvial fans may range widely in radial length, rarely up to $10 \mathrm{~km}$ in exceptional circumstances favouring particularly long runout for sediment-water mixtures (Blair, 2003), but the radial fans extent 


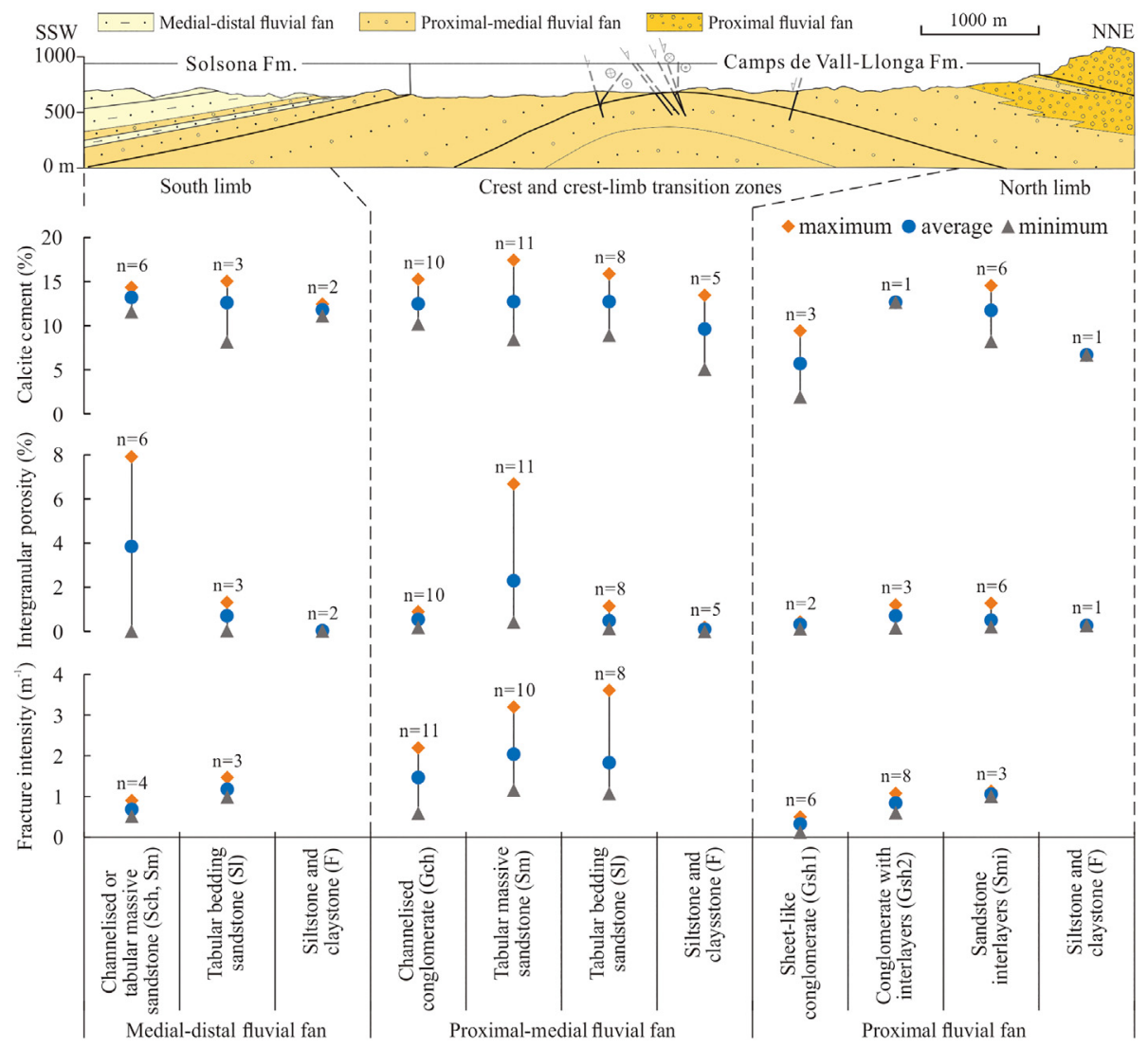

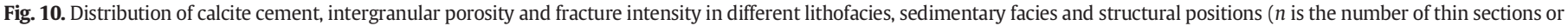
fracture scanlines sampling each lithofacies). The cross section is modified from Cruset et al. (2016). Fracture intensity data is from Sun et al. (2021b).

generally varies from several hundred metres to a few kilometres at most (Blair and McPherson, 1994a; Moscariello, 2018). The Camps de Vall-Llonga deposits spread over a large area from the Vallfogona thrust to the Puig-reig anticline. The Camps de Vall-Llonga Formation is exposed for around $9 \mathrm{~km}$ in the direction perpendicular to the Vallfogona thrust and for around $20 \mathrm{~km}$ in a direction roughly parallel to the thrust based on the studied outcrops and the regional geological map of the study area (Institut Cartogràfic i Geològic de Catalunya, 2006). Considering the folding of strata and the unexposed strata to the south, the actual extent of the Camps de Vall-Llonga deposits should be larger than the observable extent, which is larger than that of typical alluvial fans. There has been much debate regarding how alluvial fans are distinguished from distributive (fluvial) fan systems (Ventra and Clarke, 2018). In reality, there is likely a continuum between the two systems that the Camps de Vall-Llonga Formation sits close to. However, its regional drainage basin, fan size and prevalence of channelised facies indicate that they are the deposits of a distributive fluvial system (fluvial fan).

In the northwest portion of the study area, the Camps de Vall-Llonga Formation is dominated by the proximal deposits from flash floods and wide-shallow channel streams. The development of flash floods in the proximal fluvial fans is also documented in the marginal fluvial fans of the central Ebro Basin (Luzón, 2001, 2005). The channel fill deposits within flash flood conglomerates may have formed during the waning stages of flood events or developed on fan surfaces by later confined flow events (Blair and McPherson, 1994a; Nichols and Hirst, 1998). The rest of the Camps de Vall-Llonga Formation is dominated by the medial deposits from braided channel streams and overbank areas. They tend to present an overall fining-upward trend from channel fill conglomerates and sandstones to overbank fine deposits, representing cyclic (avulsive) behaviour of the system as it developed through time. In the crest-south limb transition zone of the Puig-reig anticline, the Solsona
Formation is still dominated by channel fill and overbank deposits. There are no perceptible differences of sedimentary environments in the transition area between the Camps de Vall-Llonga and Solsona formations, i.e., the contact between the lower log B1 and the upper log B2 (Fig. 6). In the south limb, conglomerate channel lags are gradually replaced by (pebbly) sandstone channel lags, i.e., in the upper log B2 and the middle $\log \mathrm{G}$ (Fig. 6). In addition, the south limb features the occasional lateral accretion of channels (Fig. 4F) and the increasing proportion of overbank areas due to less powerful discharges in the relatively distal areas. These characteristics probably indicate the gradual transition from braided channel streams to meandering channel streams, as documented in the marginal fluvial systems of the central Ebro Basin (Arenas et al., 2001; Luzón, 2005). We interpret that these deposits still belong to the medial portion of the fluvial system. This is mainly because of a lack of the terminal deposits of distal fluvial fan and the lacustrine sedimentary characteristics that have been described by Sáez et al. (2007) in the relatively central area of the eastern Ebro Basin. The Camps de Vall-Llonga and Solsona formations therefore represent mappable units rather than distinct separate sedimentary systems. The distal fluvial deposits can be found $20 \mathrm{~km}$ south of our study area. Deposits here represent terminal lobes during low lake-level stages and fluvialdominated deltas and interdistributary bays during high lake level stages (Sáez et al., 2007), which grade into evaporites and calcareous lacustrine strata near the basin centre (Del Santo et al., 2000). Based on the data measured in the Sant Llorenç de Morunys area (Williams et al., 1998; Barrier et al., 2010), palaeocurrents of the Berga Group are roughly directed towards the south to the southeast (Fig. 7C). The decrease of lithofacies associations dominated by conglomerate lithofacies and the increase of lithofacies associations dominated by sandstone and finegrained lithofacies towards the southeast (Figs. 6, 7) are consistent with the overall palaeocurrents of the Berga Group, supporting the interpretation of the proximal to medial fluvial system. 

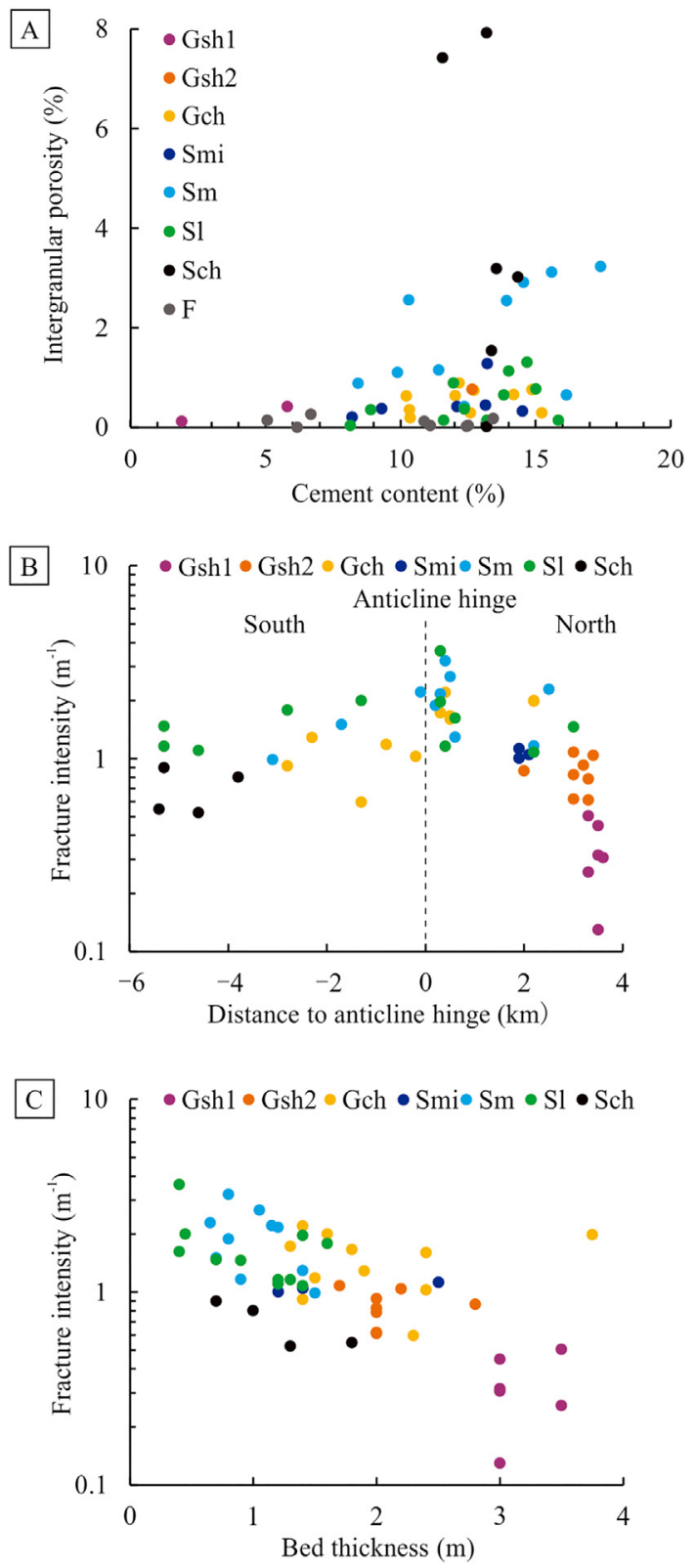

Fig. 11. (A) Crossplot between cement content and intergranular porosity. (B) Crossplot between fracture intensity and distance to anticline hinge. (C) Crossplot between fracture intensity and bed thickness. Fracture intensity data is from Sun et al. (2021b).

However, we do not discard the possibility of several alluvial fans developing during the deposition of the Berga Group, which are restricted at the northern basin margin with small fan size and local drainage basins, e.g., the small stream-flow and gravity-flow-dominated alluvial fan identified by Barrier et al. (2010) at the top of Berga Group and located to the northwest in Fig. 1D. This has been observed to be

Table 2

Trask sorting coefficient and calculated original porosity of different lithologies (Sun, 2018).

\begin{tabular}{llllll}
\hline Lithology & Siltstone & $\begin{array}{l}\text { Fine } \\
\text { sandstone }\end{array}$ & $\begin{array}{l}\text { Medium } \\
\text { sandstone }\end{array}$ & $\begin{array}{l}\text { Coarse } \\
\text { sandstone }\end{array}$ & Conglomerate \\
\hline $\begin{array}{c}\text { Range of Trask } \\
\text { sorting coefficient }\end{array}$ & $1.4-1.7$ & $1.4-2.0$ & $1.3-2.2$ & $1.3-2.3$ & $1.6-2.6$ \\
$\begin{array}{c}\text { Average original } \\
\text { porosity }\end{array}$ & 35.5 & 35.0 & 34.9 & 35.8 & 32.1 \\
\hline
\end{tabular}

the case in the northern margin of the central Ebro Basin where two distributive systems (the Luna and Huesca fluvial systems) coincide and interfinger with a series of marginal alluvial fans (Hirst and Nichols, 1986; Nichols and Hirst, 1998; Arenas et al., 2001; Luzón, 2005).

\subsection{Reservoir potential of the folded fluvial succession in the Puig-reig an- ticline}

Based on the distribution of calcite cement, intergranular porosity, fracture intensity and lithofacies characteristics in the Puig-reig anticline, we discuss the controlling factors of reservoir quality and the reservoir potential of the folded fluvial succession in the Puig-reig anticline in the SE Pyrenees.

Reservoir porosity is mainly controlled by the sedimentary characteristics of the deposits and the diagenetic processes they experience (Dos Anjos et al., 2000; Bjørlykke, 2014). In the Puig-reig anticline, two generations of calcite cement filling the intergranular porosity of the fluvial deposits have been identified. The luminescent zonation of the first-generation cement (Fig. 9A, B) indicates fluctuations of the redox conditions probably in the meteoric phreatic environment (Muchez et al., 1998; Machel, 2000). It is inferred that the earliest cement along the edges of the fluvial clasts precipitated from the meteoric phreatic environment at the early diagenetic stage. The secondgeneration cement occluded most intergranular pores, becoming the most dominant cement and resulting in an overall low porosity of the fluvial deposits (Fig. 9C, D). Based on the high temperatures observed in the clumped isotope data $\left(92{ }^{\circ} \mathrm{C}\right.$ to $\left.129^{\circ} \mathrm{C}\right)$, this cement was previously interpreted as being precipitated from external hydrothermal fluids (Cruset et al., 2016). It is inferred that the hydrothermal fluids migrated from the internal and deeper parts of the SE Pyrenees through connected thrusts and fracture networks during thrusting and folding. In the Puig-reig anticline, the fluvial deposits present an overall low porosity due to intensive compaction and calcite cementation, but which varies across the different lithofacies (Fig. 12). Relatively high porosity concentrates in lithofacies Sch and Sm in the medial fluvial fan, regardless of their relatively higher cement contents with respect to other lithofacies (Fig. 10). Compared to lithofacies Sl and F, Sch and Sm have lower contents of ductile matrix (Fig. 9C-F) due to deposited from more powerful discharges. Based on the original porosity of sandstone and siltstone (35\% on average), the porosity destroyed by compaction of lithofacies Sch and Sm mainly ranges from $40 \%$ to $70 \%$ with $57 \%$ on average, whereas that of lithofacies Sl and F mainly ranges from 55\% to 75\% with $63 \%$ on average and from $60 \%$ to $85 \%$ with $73 \%$ on average, respectively (Fig. 12A). Compared to conglomeratic lithofacies, Sch and Sm present better grain sorting and lower matrix contents, thus resulting in relatively higher original and residual porosity. Based on the original porosity of conglomerate ( $32 \%$ on average), the porosity destroyed by compaction of conglomeratic lithofacies is higher than 50\%, with $64 \%$ on average (Fig. 12B). Lithofacies Sch and Sm experience relatively weaker compaction, resulting in more residual intergranular volume which can provide more space for cementation and residual porosity. This is the main reason for the coexistence of relatively high residual porosity and calcite content in lithofacies Sch and Sm.

Based on the systematic analysis of fracture networks, the fracture distribution patterns in the Puig-reig anticline and their controlling factors have been recently studied by Sun et al. (2021b). The crest and crest-limb transition zones present relatively higher fracture intensity due to the greater curvature and finite strain they experience compared to the limbs (Figs. 10,11B), if a Tangential Longitudinal Strain model (TLS) is assumed (Hudleston and Treagus, 2010). This observation is consistent with some previous studies of fracture distribution in folds (e.g., Iñigo et al., 2012; Awdal et al., 2013; Watkins et al., 2015). If flexural slip was the dominant folding mechanism, then thin and soft layers in limbs would be ones subjected to the highest strain. However, our field data better matches the first option because the anticline crest features more intensive fracturing than the limbs. Relatively thinner 

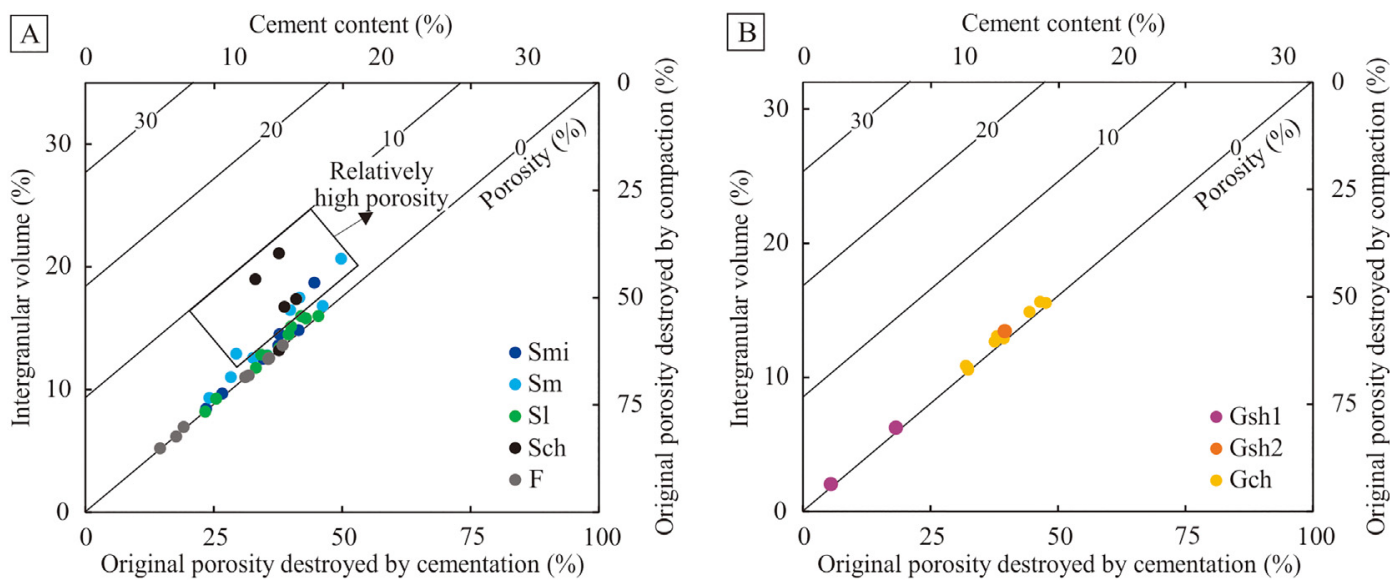

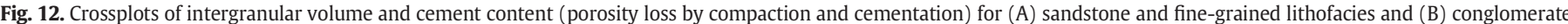
lithofacies.

sandstone layers tend to present higher fracture intensity than thick conglomerate layers in all structural positions (Figs. 10,11C). This is also consistent with some previous fracture studies that have revealed a negative correlation between fracture intensity and bed thickness (e.g., Florez-Niño et al., 2005; Wennberg et al., 2007). In addition, in the case of the same structural position and bed thickness, fracture intensity is also affected by lithofacies assemblage. For example, in the anticline crest massive sandstone with similar bed thickness present slightly different distributions of fracture spacing in different lithofacies assemblages. Sandstone layers with multiple fine-grained interlayers (Layer 1) show relatively smaller fracture spacing and thus higher fracture intensity than sandstone layers in between thick conglomerate bodies (Layer 2) and those in between thick fine-grained deposits (Layer 3) (Fig. 13) (Sun et al., 2021b). Layer 1 features the high competence contrast between competent sandstones and incompetent finegrained deposits, which favours the development of joints or faults. In
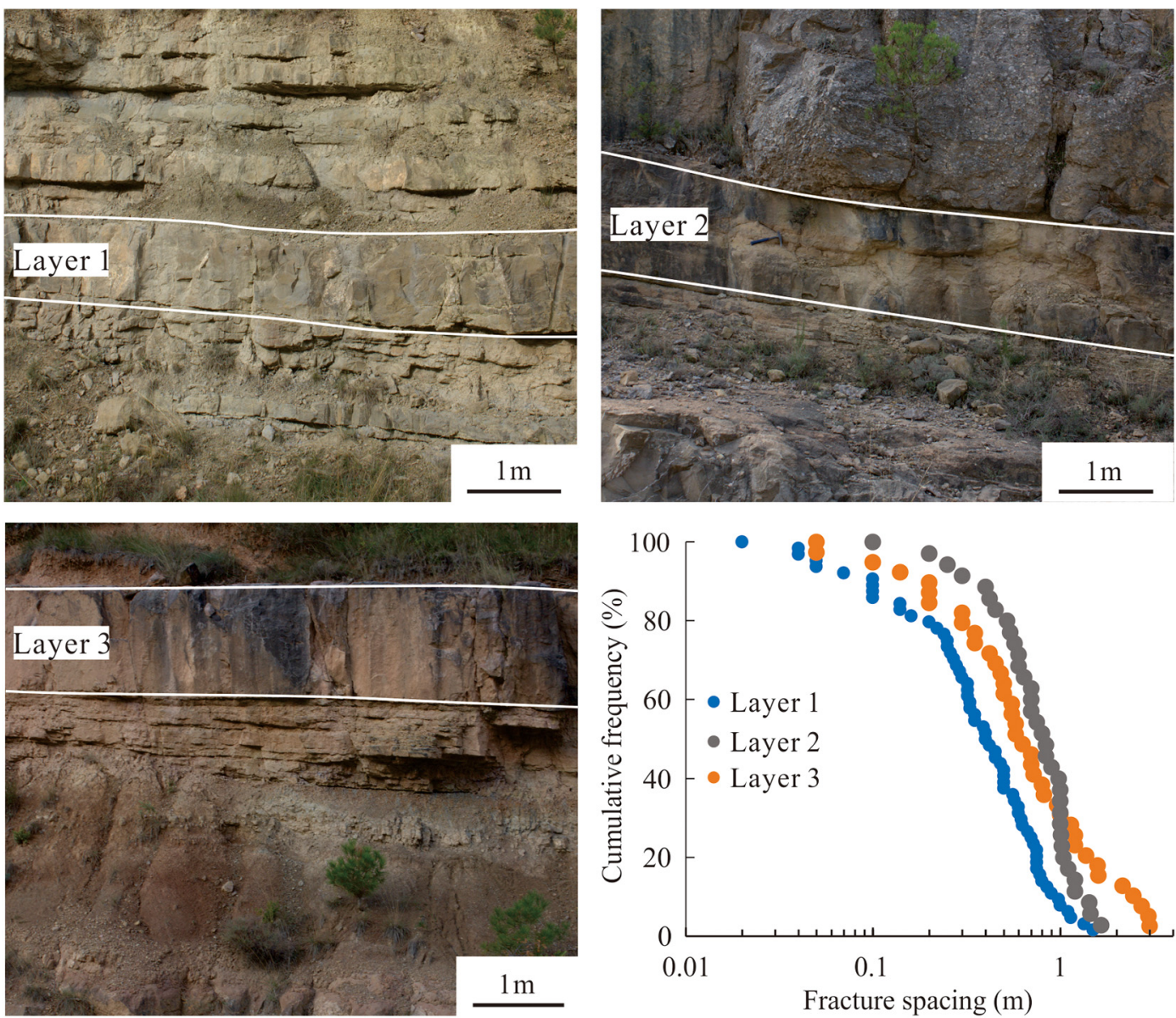


with multiple fine-grained interlayers; Layer 2: massive sandstone between thick conglomerate bodies; Layer 3: massive sandstone between thick fine-grained deposits. 
contrast, Layer 2 has relatively low competence contrast between competent sandstones and conglomerates. Although Layer 3 also features high competence contrast, thick incompetent fine-grained deposits are capable of accommodating greater amounts of pre-failure strain (Ferrill and Morris, 2008). Using multiple linear regression analysis, the relative importance of each controlling factor for controlling fracture intensity has been unravelled (Sun et al., 2021b). Fracture intensity is mainly controlled by the structural position related to the anticline hinge and is also simultaneously affected by bed thickness and lithofacies assemblage. Lithofacies Sl and Sm with multiple thin finegrained interlayers in the medial fluvial fan and located in the high strain zones of the anticline feature relatively higher fracture intensity than other structural units and lithofacies assemblages.

Based on the distribution of lithofacies, calcite cement, porosity and fracture intensity, Fig. 14 shows a schematic diagram that summarises the sedimentary characteristics and reservoir quality of the Puig-reig anticline. In the crest and crest-limb transition zones the medial fluvial sandstones present relatively greater potential to be effective reservoirs due to the high fracture intensity $\left(1-3.5 \mathrm{~m}^{-1}\right)$. The north limb presents relatively high percentages of sandstone and conglomerate deposits and lower percentages of fine-grained deposits. However, these sandstone and conglomerate deposits have low potential to become effective reservoirs due to their low porosity $(<1.5 \%)$ and fracture intensity $\left(<1.2 \mathrm{~m}^{-1}\right)$. In the south limb the medial fluvial sandstones have relatively low fracture intensity $\left(<1.5 \mathrm{~m}^{-1}\right)$, but present some reservoir potential in Sch and Sm lithofacies due to relatively high porosity (3.9\% on average).
5.3. Reservoir potential of folded alluvial-fluvial successions at foreland basin margins

As one of the dominant sedimentary systems at the active margins of non-marine foreland basins, alluvial and fluvial fans tend to present heterogeneous reservoir potential due to the interplay between complex sedimentary, diagenetic and deformation processes. Unravelling their reservoir characteristics is therefore key to the success of subsurface operations.

Compared to fluvial fans, alluvial fans present radial-limited fan extent (Blair and McPherson, 1994a). Debris-flow alluvial fans tend to present poor primary reservoir quality due to texturally immature debris deposited from debris flows and hyperconcentrated flows. These deposits have varied reservoir connectivity depending on their abundance in local sedimentary systems (Moscariello, 2018). On the other hand, water-lain alluvial fans, generally dominated by sheet floods, have better reservoir potential due to the presence of relatively better sorted deposits and reservoir connectivity (Moscariello, 2005). At basin margins, proximal fluvial deposits tend to consist of amalgamated channel belts with limited preservation of overbank deposits (Weissmann et al., 2013). Thick conglomerate bodies can occur in proximal fluvial deposits (Vincent, 2002), which can be associated with channelised noncohesive gravity or hyperconcentrated flows (Moscariello, 2018). Besides, flash floods can develop in these proximal fluvial environments, e.g., in the Puig-reig anticline and other cases (Luzón, 2001, 2005), resulting in large and coarse sheet-like deposits. Compared to debris-flow alluvial fans, these proximal fluvial deposits can have high reservoir potential

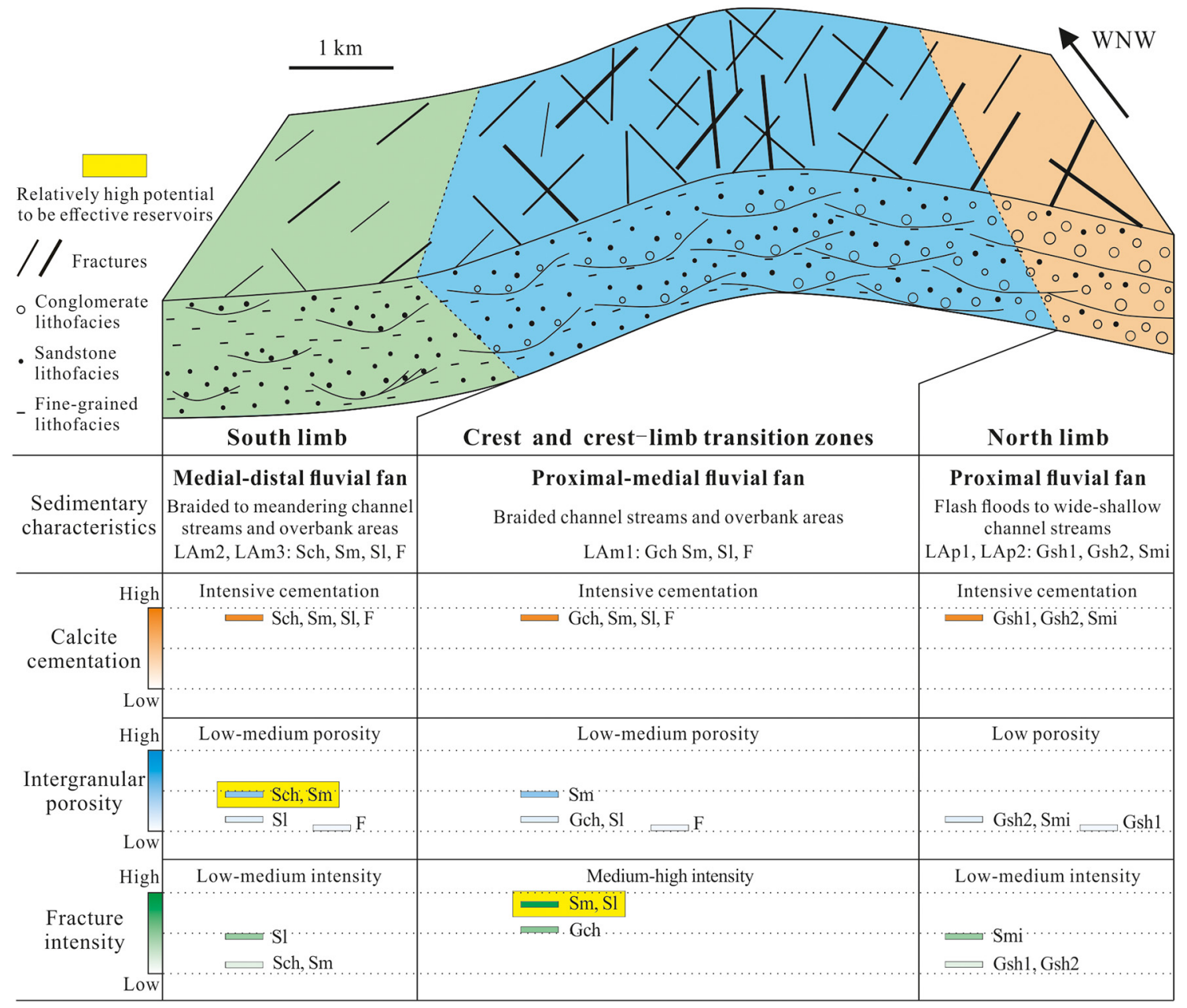

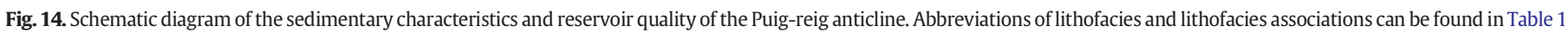
and Fig. 5, respectively. 
due to their higher textural maturity and better reservoir connectivity. Basinwards, medial deposits of fluvial fans mainly consist of channel belts separated by varied overbank fine deposits. Although these fluvial deposits present a downstream reduction of net reservoirs and a corresponding increase of overbank deposits, they are still dominated by conglomerate or sandstone reservoirs at basin margins and present better textural maturity resulting in better primary reservoir quality. These water-lain alluvial fans and proximal-medial fluvial fans present high potential to be effective reservoirs without undergoing strong compaction and cementation.

Intensive diagenesis can result in low porosity and permeability, and thus reduce the reservoir potential in alluvial-fluvial deposits (Morad et al., 2010; Lai et al., 2018). Carbonate cement is one of the prevailing authigenic minerals in these deposits (Hall et al., 2004; Taylor and Machent, 2011). In tectonically active settings, such as foreland basin margins, carbonate extrabasinal grains can become important sediments in alluvial-fluvial systems (Valloni and Zuffa, 1984; Morad et al., 2010). This is because such settings provide short time and distance for sediment transportation and exposure, thus resulting in relatively weak chemical weathering of these carbonate compositions (Zuffa, 1985). These extrabasinal carbonate grains can provide the material source for calcite cement by dissolution and favour the growth of carbonate cement by providing favourable nucleation substrates (Walderhaug and Bjørkum, 1998; Mansurbeg et al., 2009). In addition, at foreland basin margins, intensive fracturing, thrusting and folding are accompanied with fluid flow of various external geological fluids including hydrothermal, meteoric and formation fluids (Travé et al., 1997, 2000, 2007; Cruset et al., 2018, 2020). Connected fracture networks allow fluid migration across different hydrostratigraphic units (Evans and Fischer, 2012; Evans et al., 2012). These fluids can provide material sources and physical-chemical conditions from which cement precipitates (Bons et al., 2012). Thus, intensive carbonate cementation can result in an overall or localised low porosity of alluvial-fluvial deposits at basin margins, e.g., the Peraltilla and Sariñena formations in the central Ebro Basin (Yuste et al., 2004), the Berga Group and the Solsona Formation in the eastern Ebro Basin (Cruset et al., 2016), the Siwalik Group in the Himalayan Basin (Guilbaud et al., 2012), and the Wuqia Group and the Artux Formation in the southwestern Tarim Basin (Zheng et al., 2006).

At foreland basin margins, fracture networks are widely developed accompanied with intensive deformation in fold-and-thrust belts (Iñigo et al., 2012; Liu et al., 2017). These fracture networks can play a fundamental role both in fluid migration and the resulting reservoir quality, especially in reservoirs with low intergranular porosity and permeability (Casini et al., 2011; Watkins et al., 2018; Wang et al., 2020). Fracture intensity can be controlled by multiple factors in folded sedimentary successions, mainly including the structural position and the sedimentary characteristic. Fracture intensity and connectivity tend to be higher in high strain fold crests or forelimbs, such as in the cases of the Puig-reig anticline in the South-eastern Pyrenees (Sun et al., 2021b), the Achnashellach Culmination in the Southern Moine Thrust Belt (Watkins et al., 2015), or the Sub-Andean fold-thrust belt (Iñigo et al., 2012). In alluvial-fluvial deposits, variable sedimentary characteristics can exert significant effects on fracture intensity. Fracture intensity tends to present a negative correlation with bed thickness (Huang and Angelier, 1989; Florez-Niño et al., 2005). In addition, fracture intensity is also affected by lithofacies assemblages. Fractures tend to develop at the interfaces of distinct mechanical stratigraphic positions due to the high competence contrast (Sibson, 1996; Wilkins et al., 2014), such as at the interfaces between conglomerate or sandstone layers and finegrained layers. Proximal fluvial deposits are dominated by large and thick conglomerate bodies and interlayered sandstones with limited fine-grained deposits. Thus, the large bed thickness and the relatively low competence contrast between conglomerate layers or between conglomerate and sandstone layers can result in relatively low fracture intensity. In contrast, medial fluvial deposits are dominated by channel bodies with variable overbank fine deposits. The relatively high competence contrast between conglomerate or sandstone layers and finegrained layers can favour the fracture development. Besides, in the medial fluvial fan, sandstones tend to have higher fracture intensity than conglomerate bodies due to their relatively thinner bed thickness. Fracture networks can significantly improve reservoir potential in tight conglomerate and sandstone reservoirs at foreland basin margins (Watkins et al., 2018; Sun et al., 2021b).

In summary, compared to deposits in basin centre localities where reservoir quality is mainly controlled by depositional and diagenetic characteristics, basin proximal reservoirs in foreland basins are most likely to be tectonically deformed and feature variable fracture networks. Intergranular porosity is mainly controlled by primary depositional characteristics and subsequent diagenetic alteration. Fracture networks are mainly controlled by depositional characteristics and structural position. In the right circumstances, an effective combination of both structure and facies can make basin margin locations potential areas for effective reservoirs, even in the case of low porosity.

\section{Conclusions}

The lithofacies and sedimentary facies of the folded fluvial succession in the Puig-reig anticline (SE Pyrenees) have been analysed to explore the reservoir potential in the studied anticline and other similar systems at foreland basin margins. Based on a comprehensive analysis of lithofacies, porosity, cement and fracture intensity distribution, the following conclusions can be highlighted:

(1) The Camps de Vall-Llonga and Solsona formations in the Puigreig anticline were deposited as part of proximal to medial deposits of a fluvial fan system. The proximal deposits in the study area are characterised by unconfined flash floods and wide-shallow channel streams. They are dominated by thick and large sheet-like conglomerate bodies with minor interlayered sandstones, and mainly spread in the north limb of the anticline. The medial deposits are characterised by braided to meandering channel streams and overbank areas, dominated by the interbedded conglomerates, sandstones and claystones, which finally change to terminal deposits in the distal portion close to the basin centre.

(2) The fluvial deposits present overall low intergranular porosity due to intensive compaction and calcite cementation, with relatively high porosity developed in Sm and Sch lithofacies in the medial fluvial fan. Fracture intensity is mainly affected by structural position, bed thickness and lithofacies assemblage. The relatively higher values developed in sandstone lithofacies in the medial fluvial fan and located in the high strain zones of the anticline. Sandstone lithofacies deposited in the medial fluvial fan and located in the crest and crestlimb transition zones presents relatively higher potential to be effective reservoirs.

(3) The comprehensive analysis of the Puig-reig anticline can provide an effective analogue for the exploration of subsurface reservoirs. The comparison with other similar settings worldwide shows reservoir potential is comprehensively controlled by sedimentology, diagenesis and deformation at foreland basin margins. An effective combination of both structure and facies can make basin margin locations potential areas for effective reservoirs, even in the case of low intergranular porosity.

\section{Declaration of competing interest}

The authors declare that they have no known competing financial interests or personal relationships that could have appeared to influence the work reported in this paper. 


\section{Acknowledgements}

Funding was provided by the Catalan Council to the Grup Consolidat de Recerca "Geologia Sedimentària" (2017SGR-824) and the DGICYT Spanish Project PGC2018-093903-B-C22. XS acknowledges funding by the China Scholarship Council for a PhD scholarship (201806450043). JA is funded by MICINN (Juan de la Cierva fellowship - IJC2018036074-I). EGR acknowledges funding provided by the Spanish Ministry of Science, Innovation and Universities ("Ramón y Cajal" fellowship RYC2018-026335-I). We thank Enric Sangrà and Francesc Baiget for their support during field campaigns. We thank chief editor Dr. Catherine Chagué, reviewer Dr. Brian Burnham and an anonymous reviewer for their valuable suggestions, which have significantly improved this article.

\section{References}

Arenas, C., 1993. Sedimentología y paleogeografía del Terciario del margen pirenaico y sector central de la cuenca del Ebro (zona aragonesa occidental) (Ph.D. thesis). University of Zaragoza, Zaragoza, pp. 354-416 (in Spanish).

Arenas, C., Millán, H., Pardo, G., Pocoví, A., 2001. Ebro Basin continetal sedimentation associated with late compressional Pyrenean tectonics (North-Eastern lberia): controls on basin margin fans and fluvial systems. Basin Research 13, 65-89.

Awdal, A.H., Braathen, A., Wennberg, O.P., Sherwani, G.H., 2013. The characteristics of fracture networks in the Shiranish Formation of the Bina Bawi Anticline; comparison with the Taq Taq Field, Zagros, Kurdistan, NE Iraq. Petroleum Geoscience 19, 139-155.

Barrier, L., Proust, J.N., Nalpas, T., Robin, C., Guillocheau, F., 2010. Control of alluvial sedimentation at foreland-basin active margins: a case study from the northeastern Ebro Basin (southeastern Pyrenees, Spain). Journal of Sedimentary Research 80, 728-749.

Bjørlykke, K., 2014. Relationships between depositional environments, burial history and rock properties. Some principal aspects of diagenetic process in sedimentary basins. Sedimentary Geology 301, 1-14.

Blair, T.C., 2003. Features and origin of the giant Cucomungo Canyon alluvial fan, Eureka Valley, California. In: Chan, M.A., Archer, A. (Eds.), Extreme Depositional Environments: Mega End Members in Geologic Time. Geological Society of America Special Papers370, pp. 105-126.

Blair, T.C., McPherson, J.G., 1994a. Alluvial fans and their natural distinction from rivers based on morphology, hydraulic processes, sedimentary processes, and facies assemblages. Journal of Sedimentary Research 64, 450-489.

Blair, T.C., McPherson, J.G., 1994b. Alluvial fan processes and forms. In: Abrahams, A.D., Parsons, A.J. (Eds.), Geomorphology of Desert Environments. Springer, Dordrecht, pp. 354-402.

Bons, P.D., Elburg, M.A., Gomez-Rivas, E., 2012. A review of the formation of tectonic veins and their microstructures. Journal of Structural Geology 43, 33-62.

Carrigan, J.H., Anastasio, D.J., Kodama, K.P., Parés, J.M., 2016. Fault-related fold kinematics recorded by terrestrial growth strata, Sant Llorenç de Morunys, Pyrenees Mountains, NE Spain. Journal of Structural Geology 91, 161-176.

Casini, G., Gillespie, P.A., Vergés, J., Romaire, I., Fernández, N., Casciello, E., Saura, E., Mehl, C., Homke, S., Embry, J.C., Aghajari, L., Hunt, D.W., 2011. Sub-seismic fractures in foreland fold and thrust belts: Insight from the Lurestan Province, Zagros Mountains, Iran. Petroleum Geoscience 17, 263-282.

Choukroune, P., 1989. The Ecors Pyrenean deep seismic profile reflection data and the overall structure of an orogenic belt. Tectonics 8, 23-39.

Costa, E., Garcés, M., López-Blanco, M., Beamud, E., Gómez-Paccard, M., Larrasoaña, J.C., 2010. Closing and continentalization of the South Pyrenean foreland basin (NE Spain): magnetochronological constraints. Basin Research 22, 904-917.

Cruset, D., Cantarero, I., Travé, A., Vergés, J., John, C.M., 2016. Crestal graben fluid evolution during growth of the Puig-reig anticline (South Pyrenean fold and thrust belt). Journal of Geodynamics 101, 30-50.

Cruset, D., Cantarero, I., Vergés, J., John, C.M., Muñoz-López, D., Travé, A., 2018. Changes in fluid regime in syn-orogenic sediments during the growth of the south Pyrenean fold and thrust belt. Global and Planetary Change 171, 207-224.

Cruset, D., Cantarero, I., Benedicto, A., John, C.M., Vergés, J., Albert, R., Gerdes, A., Travé, A., 2020. From hydroplastic to brittle deformation: controls on fluid flow in fold and thrust belts. Insights from the Lower Pedraforca thrust sheet (SE Pyrenees). Marine and Petroleum Geology 120, 104517. https://doi.org/10.1016/j. marpetgeo.2020.104517.

de Gibert, J.M., Sáez, A., 2009. Paleohydrological significance of trace fossil distribution in Oligocene fluvial-fan-to-lacustrine systems of the Ebro Basin, Spain. Palaeogeography, Palaeoclimatology, Palaeoecology 272, 162-175.

DeCelles, P.G., Cavazza, W., 1999. A comparison of fluvial megafans in the Cordilleran (Upper Cretaceous) and modern Himalayan foreland basin systems. Geological Society of America Bulletin 111, 1315-1334.

Del Santo, G., Garcia-Sansegundo, J., Sarasa, L., Torrebadella, J., 2000. Estratigrafía y estructura del Terciario en el sector oriental de la cuenca del Ebro entre Solsona y Manresa (NE de España). Revista de la Sociedad Geológica de España 13, 265-278 (in Spanish with English abstract).

Dichiarante, A.M., McCaffrey, K.J.W., Holdsworth, R.E., Bjørnarå, T.I., Dempsey, E.D., 2020. Fracture attribute scaling and connectivity in the Devonian Orcadian Basin with implications for geologically equivalent sub-surface fractured reservoirs. Solid Earth $11,2221-2244$

Donselaar, M.E., Overeem, I., 2008. Connectivity of fluvial point-bar deposits: an example from the Miocene Huesca fluvial fan, Ebro Basin, Spain. AAPG Bulletin 92, 1109-1129.

Dos Anjos, S.M.C., De Ros, L.F., De Souza, R.S., De Assis Silva, C.M., Sombra, C.L., 2000. Depositional and diagenetic controls on the reservoir quality of Lower Cretaceous Pendencia sandstones, Potiguar rift basin, Brazil. AAPG Bulletin 84, 1719-1742.

Evans, M.A., Fischer, M.P., 2012. On the distribution of fluids in folds: A review of controlling factors and processes. Journal of Structural Geology 44, 2-24.

Evans, M.A., Bebout, G.E., Brown, C.H., 2012. Changing fluid conditions during folding: An example from the central Appalachians. Tectonophysics 576-577, 99-115.

Ferrill, D.A., Morris, A.P., 2008. Fault zone deformation controlled by carbonate mechanical stratigraphy, Balcones fault system, Texas. AAPG Bulletin 92, 359-380.

Florez-Niño, J.M., Aydin, A., Mavko, G., Antonellini, M., Ayaviri, A., 2005. Fault and fracture systems in a fold and thrust belt: an example from Bolivia. AAPG Bulletin 89, 471-493.

Folk, R.L., 1980. Petrology of Sedimentary Rocks. Hemphill Publishing Company, Austin $127 \mathrm{pp}$.

Ford, M., Williams, E.A., Artoni, A., Vergés, J., Hardy, S., 1997. Progressive evolution of a fault-related fold pair from growth strata geometries, Sant Llorenç de Morunys, SE Pyrenees. Journal of Structural Geology 19, 413-441.

Ge, H., Jackson, M.P.A., Vendeville, B.C., 1997. Kinematics and dynamics of salt tectonics driven by progradation. AAPG Bulletin 81, 398-423.

Guilbaud, R., Bernet, M., Huyghe, P., Erens, V., Chirouze, F., Dupont-Nivet, G., 2012. On the influence of diagenesis on the original petrographic composition of MiocenePliocene fluvial sandstone in the Himalayan foreland basin of western-central Nepal. Journal of Asian Earth Sciences 44, 107-116.

Hall, J.S., Mozley, P., Davis, J.M., Roy, N.D., 2004. Environments of formation and controls on spatial distribution of calcite cementation in Plio-Pleistocene fluvial deposits, New Mexico, U.S.A. Journal of Sedimentary Research 74, 643-653.

Hirst, J.P.P., Nichols, G.J., 1986. Thrust tectonic controls on Miocene alluvial distribution patterns, southern Pyrenees. In: Allen, P.A., Homewood, P. (Eds.), Foreland Basins. International Association of Sedimentologists Special Publication8, pp. 247-258.

Horton, B.K., Decelles, P.G., 2001. Modern and ancient fluvial megafans in the foreland basin system of the Central Andes, Southern Bolivia: implications for drainage network evolution in fold-thrust belts. Basin Research 13, 43-63.

Houseknecht, D.W., 1987. Assessing the relative importance of compaction processes and cementation to reduction of porosity in sandstones. AAPG Bulletin 71, 633-642.

Howell, J.A., Martinius, A.W., Good, T.R., 2014. The application of outcrop analogues in geological modelling: a review, present status and future outlook. Geological Society, London, Special Publications 387, 1-25.

Huang, Q., Angelier, J., 1989. Fracture spacing and its relation to bed thickness. Geological Magazine 126, 355-362.

Hudleston, P.J., Treagus, S.H., 2010. Information from folds: a review. Journal of Structural Geology 32, 2042-2071.

Iñigo, J.F., Laubach, S.E., Hooker, J.N., 2012. Fracture abundance and patterns in the Subandean fold and thrust belt, Devonian Huamampampa Formation petroleum reservoirs and outcrops, Argentina and Bolivia. Marine and Petroleum Geology 35 201-218.

Institut Cartogràfic i Geològic de Catalunya, 2006. Regional geological map of Catalonia. https://www.icgc.cat/en/Public-Administration-and-Enterprises/Downloads/Geological-and-geothematic-cartography/Geological-cartography/Geological-map-1-50000/Regional-geological-map-of-Catalonia-1-50-000. (Accessed 1 February 2021).

Instituto Geológico y Minero de España, 1995. Almacenamiento subterraneo de gas: previabilidad en formaciones detriticas y salinas. http://info.igme.es/ConsultaSID/r. asp?IdDESCRIPTOR=2681. (Accessed 20 March 2021).

Lai, J., Wang, G., Wang, S., Cao, J., Li, M., Pang, X., Zhou, Z., Fan, X., Dai, Q., Yang, L., He, Z., Qin, Z., 2018. Review of diagenetic facies in tight sandstones: diagenesis, diagenetic minerals, and prediction via well logs. Earth-Science Reviews 185, 234-258.

Liu, C., Zhang, R., Zhang, H., Wang, J., Mo, T., Wang, K., Zhou, L., 2017. Genesis and reservoir significance of multi-scale natural fractures in Kuqa foreland thrust belt, Tarim Basin, NW China. Petroleum Exploration and Development 44, 495-504.

Luzón, A., 2001. Análisis tectosedimentario de los materiales terciarios continentales del sector central de la cuenca del Ebro (provincias de Huesca y Zaragoza) (Ph.D. thesis). Zaragoza University, Zaragoza (in Spanish).

Luzón, A., 2005. Oligocene-Miocene alluvial sedimentation in the northern Ebro Basin, NE Spain: tectonic control and palaeogeographical evolution. Sedimentary Geology 177, 19-39.

Machel, H.G., 2000. Application of cathodoluminescence to carbonate diagenesis. In: Page, M., Barbin, V., Blanc, P., Ohnenstetter, D. (Eds.), Cathodoluminescence in Geosciences. Springer, Berlin, Heidelberg, pp. 271-301.

Mann, P., Gahagan, L., Gordon, M.B., 2003. Tectonic setting of the world's giant oil fields In: Halbouty, M. (Ed.), Giant Oil and Gas Fields of the Decade 1990-1999. AAPG Memoir78, pp. 15-105.

Mansurbeg, H., Caja, M.A., Marfil, R., Morad, S., Remacha, E., Garcia, D., Martin-Crespo, T., El-Ghali, M.A.K., Nystuen, J.P., 2009. Diagenetic evolution and porosity destruction of turbiditic hybrid arenites and siliciclastic sandstones of foreland basins: evidence from the Eocene Hecho Group, Pyrenees, Spain. Journal of Sedimentary Research 79, 711-735.

Martin, B., Owen, A., Nichols, G.J., Hartley, A.J., Williams, R.D., 2021. Quantifying downstream, vertical and lateral variation in fluvial deposits: implications from the Huesca distributive fluvial system. Frontiers in Earth Science 8, 564017. https://doi.org/10. 3389/feart.2020.564017.

Martínez-Martínez, J.M., Soto, J.I., Balanyá, J.C., 2002. Orthogonal folding of extensional detachments: structure and origin of the Sierra Nevada elongated dome (Betics, SE Spain). Tectonics 21, 1-22. 
Morad, S., Al-Ramadan, K., Ketzer, J.M., De Ros, L.F., 2010. The impact of diagenesis on the heterogeneity of sandstone reservoirs: a review of the role of depositional fades and sequence stratigraphy. AAPG Bulletin 94, 1267-1309.

Moscariello, A., 2005. Exploration potential of the mature Southern North Sea basin margins: some unconventional plays based on alluvial and fluvial fan sedimentation models. In: Doré, A.G., Vining, B.A. (Eds.), Petroleum Geology: North-West Europe and Global Perspectives - Proceedings of the 6th Petroleum Geology Conference. Geological Society of London, pp. 595-605.

Moscariello, A., 2018. Alluvial fans and fluvial fans at the margins of continental sedimentary basins: geomorphic and sedimentological distinction for geo-energy exploration and development. Geological Society, London, Special Publications 440, 215-243.

Muchez, P., Nielsen, P., Sintubin, M., Lagrou, D., 1998. Conditions of meteoric calcite formation along a Variscan fault and their possible relation to climatic evolution during the Jurassic-Cretaceous. Sedimentology 45, 845-854.

Muñoz, J.A., 1992. Evolution of a continental collision belt: ECORS-Pyrenees crustal balanced cross-section. In: McClay, K.R. (Ed.), Thrust Tectonics. Springer, Dordrecht, pp. 235-246.

Nichols, G., 2005. Tertiary alluvial fans at the northern margin of the Ebro Basin: a review. Geological Society, London, Special Publications 251, 187-206.

Nichols, G., Hirst, J.P., 1998. Alluvial fans and fluvial distributary systems, Oligo-Miocene, northern Spain; contrasting processes and products. Journal Sedimentary Research $68,879-889$.

Puigdefàbregas, C., Munñz, J.A., Marzo, M., 1986. Thrust belt development in the eastern Pyrenees and related depositional sequences in the southern foreland basin. In: Allen, P.A., Homewood, P. (Eds.), Foreland Basins. International Association of Sedimentologists Special Publication8, pp. 229-246.

Puigdefàbregas, C., Muñoz, J.A., Vergés, J., 1992. Thrusting and foreland basin evolution in the Southern Pyrenees. In: McClay, K.R. (Ed.), Thrust Tectonics. Springer, Dordrecht, pp. 247-254.

Riba, O., 1976. Syntectonic unconformities of the Alto Cardener, Spanish Pyrenees: a genetic interpretation. Sedimentary Geology 15, 213-233.

Roure, F., Choukroune, P., Berastegui, X., Munoz, J.A., Villien, A., Matheron, P., Bareyt, M., Seguret, M., Camara, P., Deramond, J., 1989. Ecors deep seismic data and balanced cross sections: geometric constraints on the evolution of the Pyrenees. Tectonics 8, $41-50$.

Sáez, A., 1987. Estratigrafía y sedimentología de las formaciones lacustres del tránsito Eoceno-Oligoceno del NE de la Cuenca del Ebro (Ph.D. thesis). University of Barcelona, Barcelona, pp. 23-135 (in Spanish).

Sáez, A., Anadón, P., Herrero, M.J., Moscariello, A., 2007. Variable style of transition between Palaeogene fluvial fan and lacustrine systems, southern Pyrenean foreland, NE Spain. Sedimentology 54, 367-390.

Scherer, M., 1987. Parameters influencing porosity in sandstones: a model for sandstone porosity prediction. AAPG Bulletin 71, 485-491.

Schneider, C.A., Rasband, W.S., Eliceiri, K.W., 2012. NIH image to ImageJ: 25 years of image analysis. Nature Methods 9, 671-675.

Serra-Kiel, J., Mató, E., Saula, E., Travé, A., Ferràndez-Canadell, C., Busquets, P., Samsó, J.M., Tosquella, J., Barnolas, A., Àlvarez-Pérez, G., Franquès, J., Romero, J., 2003a. An inventory of the marine and transitional Middle/Upper Eocene deposits of the Southeastern Pyrenean Foreland Basin (NE Spain). Geologica Acta 1, 201-229.

Serra-Kiel, J., Travé, A., Mató, E., Saula, E., Ferràndez-Canadell, C., Busquets, P., Tosquella, J., Vergés, J., 2003b. Marine and transitional Middle/Upper Eocene units of the Southeastern Pyrenean Foreland Basin (NE Spain). Geologica Acta 1, 177-200.

Sibson, R.H., 1996. Structural permeability of fluid-driven fault-fracture meshes. Journal of Structural Geology 18, 1031-1042.

Sun, X., 2018. Pore Structure Characterization of Low Permeability and Tight Sandstone Reservoirs of Huagang Formation in Xihu Depression (M.Sc. thesis). China University of Petroleum (East China), Qingdao, pp. 45-46 (in Chinese with English abstract).

Sun, X., Alcalde, J., Gomez-Rivas, E., Struth, L., Johnson, G., Travé, A., 2020. Appraisal of CO2 storage potential in compressional hydrocarbon-bearing basins: global assessment and case study in the Sichuan Basin (China). Geoscience Frontiers 11, 2309-2321.

Sun, X., Alcalde, J., Bakhtbidar, M., Elío, J., Vilarrasa, V., Canal, J., Ballesteros, J., Heinemann, N., Haszeldine, S., Cavanagh, A., Vega-Maza, D., Rubiera, F., Martínez-Orio, R., Johnson, G., Carbonell, R., Marzan, I., Travé, A., Gomez-Rivas, E., 2021a. Hubs and clusters approach to unlock the development of carbon capture and storage - case study in Spain. Applied Energy 300, 117418. https://doi.org/10.1016/j.apenergy.2021.117418.

Sun, X., Gomez-Rivas, E., Alcalde, J., Martín-Martín, J.D., Ma, C., Muñoz-López, D., Cruset, D., Cantarero, I., Griera, A., Travé, A., 2021b. Fracture distribution in a folded fluvial succession: the Puig-reig anticline (South-eastern Pyrenees). Marine and Petroleum Geology 132, 105169. https://doi.org/10.1016/j.marpetgeo.2021.105169.

Suppe, J., Sàbat, F., Anton Muñoz, J., Poblet, J., Roca, E., Vergés, J., 1997. Bed-by-bed fold growth by kink-band migration: Sant llorenç de Morunys, eastern Pyrenees. Journal of Structural Geology 19, 443-461.

Taylor, K.G., Machent, P.G., 2011. Extensive carbonate cementation of fluvial sandstones: an integrated outcrop and petrographic analysis from the Upper Cretaceous, Book Cliffs, Utah. Marine and Petroleum Geology 28, 1461-1474

Taylor, T.R., Giles, M.R., Hathon, L.A., Diggs, T.N., Braunsdorf, N.R., Birbiglia, G.V., Kittridge, M.G., MacAulay, C.I., Espejo, I.S., 2010. Sandstone diagenesis and reservoir quality prediction: models, myths, and reality. AAPG Bulletin 94, 1093-1132.

Travé, A., Labaume, P., Calvet, F., Soler, A., 1997. Sediment dewatering and pore fluid migration along thrust faults in a foreland basin inferred from isotopic and elemental geochemical analyses (Eocene southern Pyrenees, Spain). Tectonophysics 282, 375-398.
Travé, A., Calvet, F., Sans, M., Vergés, J., Thirlwall, M., 2000. Fluid history related to the Alpine compression at the margin of the south-Pyrenean Foreland basin: the El Guix anticline. Tectonophysics 321, 73-102.

Travé, A., Labaume, P., Vergés, J., 2007. Fluid systems in foreland fold-and-thrust belts: an overview from the southern Pyrenees. In: Lacombe, O., Lavé, J., Roure, F., Vergés, J. (Eds.), Thrust Belts and Foreland Basins. Springer, Berlin, Heidelberg, pp. 93-115.

Valloni, R., Zuffa, G.G., 1984. Provenance changes for arenaceous formations of the northern Apennines, Italy. Geological Society of America Bulletin 95, 1035-1039.

Ventra, D., Clarke, L.E., 2018. Geology and geomorphology of alluvial and fluvial fans: current progress and research perspectives. Geological Society, London, Special Publications 440, 1-21.

Vergés, J., 1993. Estudi geològic del vessant sud del Pirineu oriental i central. Evolució cinemàtica en 3D (Ph.D. thesis). University of Barcelona, Barcelona, pp. 46-63 (in Spanish).

Vergés, J. 2007. Drainage responses to oblique and lateral thrust ramps: a review. In: Nichols, G., Paola, C., Williams, E.A. (Eds.), Sedimentary Processes. Environments and Basins: A Tribute to Peter Friend. International Association of Sedimentologists Special Publication38, pp. 29-47.

Vergés, J., Muñoz, J.A., Martínez, A., 1992. South Pyrenean fold and thrust belt: The role of foreland evaporitic levels in thrust geometry. In: McClay, K.R. (Ed.), Thrust Tectonics. Springer, Dordrecht, pp. 255-264.

Vergés, J., Marzo, M., Santaeulària, T., Serra-Kiel, J. Burbank, D.W., Muñoz, J.A GiménezMontsant, J., 1998. Quantified vertical motions and tectonic evolution of the SE Pyrenean foreland basin. Geological Society, London, Special Publications 134, 107-134.

Vergés, J., Marzo, M., Muñoz, J.A., 2002. Growth strata in foreland settings. Sedimentary Geology 146, 1-9.

Vincent, S.J., 2002. The Sis palaeovalley: a record of proximal fluvial sedimentation and drainage basin development in response to Pyrenean mountain building. Sedimentology 48, 1235-1276.

Walderhaug, O., Bjørkum, P.A., 1998. Calcite cement in shallow marine sandstones: growth mechanisms and geometry. In: Morad, S. (Ed.), Carbonate Cementation in Sandstones. International Association of Sedimentologists Special Publication26, pp. 179-192.

Wang, H., Ma, F., Tong, X., Liu, Z., Zhang, X., Wu, Z., Li, D., Wang, B., Xie, Y., Yang, L., 2016. Assessment of global unconventional oil and gas resources. Petroleum Exploration and Development 43, 925-940.

Wang, Z., Lü, X., Wang, S., Li, Y., Zhou, X., Quan, H., Li, R., 2020. Fracture systems and petrophysical properties of tight sandstone undergoing regional folding: a case study of the Cretaceous reservoirs in the Kuqa foreland thrust belt, Tarim Basin. Marine and Petroleum Geology 111, 104055. https://doi.org/10.1016/j.marpetgeo.2019. 104055.

Watkins, H., Butler, R.W.H., Bond, C.E., Healy, D., 2015. Influence of structural position on fracture networks in the Torridon Group, Achnashellach fold and thrust belt, NW Scotland. Journal of Structural Geology 74, 64-80.

Watkins, H., Healy, D., Bond, C.E., Butler, R.W.H., 2018. Implications of heterogeneous fracture distribution on reservoir quality: an analogue from the Torridon Group sandstone, Moine Thrust Belt, NW Scotland. Journal of Structural Geology 108, 180-197.

Weissmann, G.S., Hartley, A.J., Scuderi, L.A., Nichols, G.J., Davidson, S.K., Owen, A., Atchley, S.C., Bhattacharyya, P., Chakraborty, T., Ghosh, P., Nordt, L.C., Michel, L., Tabor, N.J., 2013. Prograding distributive fluvial systems-geomorphic models and ancient examples. In: Driese, S.G., Nordt, Lee C. (Eds.), New Frontiers in Paleopedology and Terrestrial Paleoclimatology: Paleosols and Soil Surface Analog Systems. 104. Society for Sedimentary Geology Special Publication, pp. 131-147.

Weissmann, G.S., Hartley, A.J., Scuderi, L.A., Nichols, G.J., Owen, A., Wright, S., Felicia, A.L Holland, F., Anaya, F.M.L., 2015. Fluvial geomorphic elements in modern sedimentary basins and their potential preservation in the rock record: a review. Geomorphology 250, 187-219.

Wennberg, O.P., Azizzadeh, M., Aqrawi, A.A.M., Blanc, E., Brockbank, P., Lyslo, K.B., Pickard, N., Salem, L.D., Svånå, T., 2007. The Khaviz Anticline: an outcrop analogue to giant fractured Asmari Formation reservoirs in SW Iran. Geological Society, London, Special Publications 270, 23-42.

Wilkins, S., Mount, V., Mahon, K., Perry, A., Koenig, J., 2014. Characterization and development of subsurface fractures observed in the Marcellus Formation, Appalachian Plateau, north-central Pennsylvania. AAPG Bulletin 98, 2301-2345.

Williams, E.A., Ford, M., Vergés, J., Artoni, A., 1998. Alluvial gravel sedimentation in a contractional growth fold setting, Sant Llorenç de Morunys, southeastern Pyrenees. Geological Society, London, Special Publications 134, 69-106.

Yuste, A., Luzón, A., Bauluz, B., 2004. Provenance of Oligocene-Miocene alluvial and fluvial fans of the northern Ebro Basin (NE Spain): an XRD, petrographic and SEM study. Sedimentary Geology 172, 251-268.

Zhang, R., Yao, G., Shou, J., Zhang, H., Tian, J., 2011. An integration porosity forecast mode of deposition, diagenesis and structure. Petroleum Exploration and Development 38, $145-151$.

Zheng, H., Huang, X., Butcher, K., 2006. Lithostratigraphy, petrography and facies analysis of the Late Cenozoic sediments in the foreland basin of the West Kunlun. Palaeogeography, Palaeoclimatology, Palaeoecology 241, 61-78.

Zuffa, G.G., 1980. Hybrid arenites: their composition and classification. Journal of Sedimentary Research 50, 21-29.

Zuffa, G.G., 1985. Optical analyses of arenites: Influence of methodology on compositional results. In: Zuffa, G.G. (Ed.), Provenance of Arenites: NATO-Advanced Study Institute Series C. Reidel Publishing Company, Dordrecht, pp. 165-189. 